\title{
Screening of Purslane (Portulaca oleracea L.) Accessions for High Salt Tolerance
}

\author{
Md. Amirul Alam, ${ }^{1}$ Abdul Shukor Juraimi, ${ }^{1}$ M. Y. Rafii, ${ }^{1,2}$ \\ Azizah Abdul Hamid, ${ }^{3}$ and Farzad Aslani ${ }^{1}$ \\ ${ }^{1}$ Department of Crop Science, Faculty of Agriculture, Universiti Putra Malaysia, 43400 Serdang, Selangor, Malaysia \\ ${ }^{2}$ Institute of Tropical Agriculture, Universiti Putra Malaysia, 43400 Serdang, Selangor, Malaysia \\ ${ }^{3}$ Faculty of Food Science and Technology, Universiti Putra Malaysia, 43400 Serdang, Selangor, Malaysia
}

Correspondence should be addressed to Md. Amirul Alam; amirul81@gmail.com

Received 18 March 2014; Revised 8 May 2014; Accepted 8 May 2014; Published 9 June 2014

Academic Editor: Luigi Cattivelli

Copyright (C) $2014 \mathrm{Md}$. Amirul Alam et al. This is an open access article distributed under the Creative Commons Attribution License, which permits unrestricted use, distribution, and reproduction in any medium, provided the original work is properly cited.

Purslane (Portulaca oleracea L.) is an herbaceous leafy vegetable crop, comparatively more salt-tolerant than any other vegetables with high antioxidants, minerals, and vitamins. Salt-tolerant crop variety development is of importance due to inadequate cultivable land and escalating salinity together with population pressure. In this view a total of 25 purslane accessions were initially selected from 45 collected purslane accessions based on better growth performance and subjected to 5 different salinity levels, that is, 0.0 , $10.0,20.0,30.0$, and $40.0 \mathrm{dS} \mathrm{m}^{-1} \mathrm{NaCl}$. Plant height, number of leaves, number of flowers, and dry matter contents in salt treated purslane accessions were significantly reduced $(P \leq 0.05)$ and the enormity of reduction increased with increasing salinity stress. Based on dry matter yield reduction, among all 25 purslane accessions 2 accessions were graded as tolerant (Ac7 and Ac9), 6 accessions were moderately tolerant (Ac3, Ac5, Ac6, Ac10, Ac11, and Ac12), 5 accessions were moderately susceptible (Ac1, Ac2, Ac4, Ac8, and Ac13), and the remaining 12 accessions were susceptible to salinity stress and discarded from further study. The selected 13 purslane accessions could assist in the identification of superior genes for salt tolerance in purslane for improving its productivity and sustainable agricultural production.

\section{Introduction}

Salinity is regarded as a momentous situation worldwide because it has been projected that salinity will affect $30 \%$ of arable world land area within the next 25 years and about $50 \%$ of land area by the end of this century [1]. Each year, more and more land becomes nonproductive owing to salt accumulation. Salt stress can affect germination, growth, and productivity of crops as well as weeds [2]. It is now well established that salinity can affect the plant growth by altering their morphological, physiological, and biochemical as well as anatomical characteristics [3] (Tester and Davenport, 2003). Crops grown in salt affected soils may suffer from osmotic imbalance, ion toxicity, and mineral insufficiency leading to abridged growth and productivity $[4,5]$ and cellular dehydration is a common effect of osmotic stresses, together with water deficiency at elevated salinity levels $[6,7]$.
Plants grown in soils with high salt levels can also exhibit poor vegetative growth and/or symptoms with leaf sclerosis [8]. In addition, salt stress is also associated with different biotic and abiotic stresses in plants and limited their growth and development [9].

The detection of salinity-induced injuries, however, is very complex even under controlled conditions. The visual symptoms of salt stress may still be the most appropriate for mass screening. Salt injury in purslane starts with shedding of leaves and reduction of leaf area with losing of greenness and gradually stops blooming. At long time high salinity stress changing of stem color to more reddish or pinkish is also observed. The typical means of salinity tolerance is the exclusion or reduction of $\mathrm{Na}$ uptake and augmented assimilation of $\mathrm{K}$ to uphold a good $\mathrm{Na}-\mathrm{K}$ equilibrium in the vegetative plant parts. Screening for salt tolerance has been undertaken worldwide using a diversity of culture techniques 
through plant materials ranging from germinating seeds through seedlings to mature plants in various crops by several scientists, in Jute [10], in Millet [11], in Sorghum [12, 13], in Rice $[14,15]$, in Pea [16], in Turfgrass [17], in Alfalfa [18], and in Wheat [2].

Cultivation of salt-tolerant species and cultivars in the salt problem soils is a substitute retrieval practice. Selection of salt-tolerant plants from salty fields or plots looks like a rational footstep for the majority plant breeders. Unluckily, the most salt-tolerant species are usually not the most productive or enviable. Due to increasing land salinization problems in the world, breeding for salinity tolerance in crops needs to pay more attention. To minimize the continuous increasing pressure of population growth on food supplies and resources, marginal land and the available water can be utilized for growing drought and saline-tolerant cultivars of different vegetables including purslane, which fills a unique and highly significant place in drought and salinity tolerance in arid zones compared to other crops [19]. The cash value of vegetable crop is always higher compared to field crops, so salt tolerance in vegetable crop is very essential [20]. Purslane is a vegetable crop species that can tolerate moderate to high salinity stress and is able to produce economic amount of dry mass even at higher salinity stress. The relative salt tolerance among different purslane cultivars has not been adequately studied yet. The proper utilization of highly salttolerant purslane species will give benefit to purslane growing area in Malaysia and throughout the world. So, the objectives of this study were to screen the most salt-tolerant purslane accessions prioritizing the use of this potential crop as a source of vegetable nutrients and its commercial cultivation especially for saline agriculture and sustainable development.

\section{Materials and Methods}

2.1. Experimental Site and Soil. The plastic pot $(24 \times 22 \times$ $20 \mathrm{~cm}$ ) experiment was conducted during April 2013 to June 2013 in the glasshouse of Field-2 at the Faculty of Agriculture, Universiti Putra Malaysia $\left(3^{\circ} 00^{\prime} 21.34^{\prime \prime} \mathrm{N}, 101^{\circ} 42^{\prime} 15.06^{\prime \prime} \mathrm{E}\right.$, $37 \mathrm{~m}$ elevation). The plastic pots were filled with soil $(39.51 \%$ sand, $9.03 \%$ silt, and $51.35 \%$ clay) of $\mathrm{pH} 4.8$ with $2.6 \%$ organic carbon, $1.24 \mathrm{~g} \mathrm{cc}^{-1}$ bulk density, and CEC of $7.07 \mathrm{meq}+/ 100 \mathrm{~g}$ dry soil. Soil nutrient status was $0.16 \%$ total N, 5.65 ppm available P, 15.3 ppm available K, 3295 ppm Ca, and 321 ppm Mg. At field capacity, soil water retention was $31.18 \%$ (wet basis) and $45.31 \%$ (dry basis). The experimental soil belongs to the Serdang series.

2.2. Plant Materials and Experimental Design. Seedlings of the 12 common purslanes and cuttings of the 13 ornamental purslane accessions (as ornamental purslane does not produce seed) were selected from 45 collected purslane accessions of a previous experiment based on better vegetative growth of the plants and transplanted into the pots with prepared soils. The experiment was organized in a twofactor (purslane accessions $\times$ salinity) factorial randomized complete block design with three replications. Locations of collection and a brief phenotypic description of the 25 purslane accessions have been provided in Table 1.

\subsection{Planting, Cultural Practices, and Treatment Application.}

Ten-day-old five seedlings or cuttings for each accession were transplanted in plastic pots filled with the field top soil mentioned above. The plants were allowed to recover from transplanting shock and for full establishment for 29 days. During this time, plants were irrigated with tap water as and when necessary. No fertilizer was used. Five salinity treatments $\left(0,10.0,20.0,30.0\right.$, and $\left.40.0 \mathrm{dS} \mathrm{m}^{-1}\right)$ were applied in this study prepared using $\mathrm{NaCl}$ (Merck, Darmstadt, Germany) and distilled water. Salt treatment was initiated 30 days after transplanting (DAT) and continued till end of the study. In each pot, $200 \mathrm{~mL}$ of saline water was applied on alternate days according to the treatment. The control plants received $200 \mathrm{~mL}$ of distilled water.

\subsection{Data Collection}

2.4.1. Plant Height. Sixty-day-old plant heights were measured in $\mathrm{cm}$ from five plants of each pot and then averaged to get the mean plant height. The mean plant height reduction due to different salinity stress was then calculated compared to untreated control plants.

2.4.2. Number of Leaves. The total number of leaves of each plant was counted from each pot and averaged to calculate mean number of leaves. The mean number of shedding of leaves due to different salinity stress was then calculated compared to untreated control plants.

2.4.3. Number of Flowers. Purslane blooms everyday so total numbers of flowers were counted daily and recorded. At the end before harvesting the total numbers of flowers were averaged to calculate the mean number of flowers. The mean number of flowering reduction due to different salinity stress was then calculated compared to untreated control plants.

2.4.4. Total Dry Matter. For initial drying just after harvesting the fresh samples (except root) were stored in a cool dry place for 3 days, then kept in oven at $40^{\circ} \mathrm{C}$ temperature for 3 days (making them dry and preventing them from sudden burning injury), and then transferred to $70^{\circ} \mathrm{C}$ for another 72 hours to get constant weight. The mean dry weight (DW) loss due to salinity stress was then calculated from this oven-dried sample compared to untreated control plants. The percentage (\%) of yield loss was measured using the following formula:

$$
\begin{aligned}
& \text { Percentage }(\%) \text { of yield loss } \\
& =\frac{\text { Control treatment value }- \text { Salinized treatment value }}{\text { Control treatment value }} \\
& \quad \times 100 \text {. }
\end{aligned}
$$

Purslane accessions were classified and selected based on their total dry matter reduction due to different levels of 
TABLE 1: Brief morphological descriptions and collection details of 25 selected purslane samples.

\begin{tabular}{|c|c|c|c|c|c|c|}
\hline $\begin{array}{l}\text { Accession } \\
\text { number }\end{array}$ & $\begin{array}{l}\text { Sample } \\
\text { code }\end{array}$ & State & Locations & $\begin{array}{l}\text { Latitude } \\
\left({ }^{\circ} \mathrm{N}\right)\end{array}$ & $\begin{array}{c}\text { Longitude } \\
\left({ }^{\circ} \mathrm{E}\right)\end{array}$ & $\begin{array}{l}\text { Brief morphology of the collected purslane } \\
\text { plants }\end{array}$ \\
\hline Acl & Slg-1 & Selangor & Sungai Buloh & $03^{\circ} 19^{\prime}$ & $101^{\circ} 59^{\prime}$ & $\begin{array}{l}\text { Pink flower, wedge shaped margin red green } \\
\text { leaf, red stem }\end{array}$ \\
\hline Ac2 & Slg-2 & Selangor & Sungai Buloh & $03^{\circ} 19^{\prime}$ & $101^{\circ} 59^{\prime}$ & $\begin{array}{l}\text { White-pink colored flower, wedge shaped } \\
\text { green leaf, red stem }\end{array}$ \\
\hline Ac3 & Slg-3 & Selangor & Sungai Buloh & $03^{\circ} 19^{\prime}$ & $101^{\circ} 59^{\prime}$ & $\begin{array}{l}\text { Yellow flower, paddle shaped green leaf, red } \\
\text { stem }\end{array}$ \\
\hline Ac4 & Slg-4 & Selangor & AgroBio. UPM & $02^{\circ} 98^{\prime}$ & $101^{\circ} 73^{\prime}$ & $\begin{array}{l}\text { Yellow flower, red margin wedge shaped green } \\
\text { leaf, red stem }\end{array}$ \\
\hline Ac5 & Slg-5 & Selangor & UPM & $03^{\circ} 01^{\prime}$ & $101^{\circ} 71^{\prime}$ & $\begin{array}{l}\text { Wild, yellow flower, wedge shaped green leaf, } \\
\text { green-red stem }\end{array}$ \\
\hline Ac7 & Slg-7 & Selangor & Tanjung Karang & $03^{\circ} 41^{\prime}$ & $101^{\circ} 19^{\prime}$ & $\begin{array}{l}\text { Yellow flower, paddle shaped green leaf, red } \\
\text { stem. }\end{array}$ \\
\hline Ac8 & Slg-8 & Selangor & Tanjung Karang & $03^{\circ} 41^{\prime}$ & $101^{\circ} 19^{\prime}$ & Pink flower, paddle shaped green leaf, red stem. \\
\hline Ac9 & Slg-9 & Selangor & Nursery, Klang & $03^{\circ} 02^{\prime}$ & $101^{\circ} 26^{\prime}$ & $\begin{array}{l}\text { Purple flower, wedge shaped red-green leaf, } \\
\text { pink stem }\end{array}$ \\
\hline Ac10 & Slg-10 & Selangor & Nursery, Klang & $03^{\circ} 02^{\prime}$ & $101^{\circ} 26^{\prime}$ & $\begin{array}{l}\text { Pink flower, wedge shaped green leaf, } \\
\text { green-red stem }\end{array}$ \\
\hline Ac12 & Mlk-1 & Melaka & $\begin{array}{l}\text { Kg. Pulau } \\
\text { Gadong }\end{array}$ & $02^{\circ} 24^{\prime}$ & $102^{\circ} 21^{\prime}$ & $\begin{array}{l}\text { Wild, yellow flower, wedge shaped green leaf, } \\
\text { red-green stem }\end{array}$ \\
\hline Ac17 & PD-1 & $\begin{array}{l}\text { Negeri } \\
\text { Sembilan }\end{array}$ & $\begin{array}{l}\text { Kg. Ayer } \\
\text { Meleleh }\end{array}$ & $02^{\circ} 54^{\prime}$ & $101^{\circ} 80^{\prime}$ & $\begin{array}{l}\text { Wild, yellow flower, paddle shaped green leaf, } \\
\text { red-green stem }\end{array}$ \\
\hline Ac22 & Kdh-1 & Kedah & Nursery, Kedah & $06^{\circ} 11^{\prime}$ & $100^{\circ} 37^{\prime}$ & $\begin{array}{l}\text { Orange-yellow flower, wedge shaped green leaf, } \\
\text { red stem }\end{array}$ \\
\hline Ac23 & Kdh-2 & Kedah & Nursery, Kedah & $06^{\circ} 11^{\prime}$ & $100^{\circ} 37^{\prime}$ & Pink flower, wedge shaped green leaf, red stem \\
\hline Ac24 & Kdh-3 & Kedah & Nursery, Kedah & $06^{\circ} 11^{\prime}$ & $100^{\circ} 37^{\prime}$ & $\begin{array}{l}\text { Purple flower, paddle shaped green leaf, red } \\
\text { stem }\end{array}$ \\
\hline Ac25 & Kdh-4 & Kedah & Kuala Kedah & $06^{\circ} 11^{\prime}$ & $100^{\circ} 29^{\prime}$ & $\begin{array}{l}\text { Wild, yellow flower, green wedge shaped leaf, } \\
\text { green stem }\end{array}$ \\
\hline Ac27 & Kdh-6 & Kedah & Jitra-1 & $06^{\circ} 24^{\prime}$ & $100^{\circ} 43^{\prime}$ & $\begin{array}{l}\text { Wild, yellow flower, green wedge shaped leaf, } \\
\text { green-red stem }\end{array}$ \\
\hline Ac31 & Prk-1 & Perak & Kuala Kangsar & $04^{\circ} 77^{\prime}$ & $100^{\circ} 94^{\prime}$ & $\begin{array}{l}\text { Wild, yellow flower, wedge shaped green-red } \\
\text { leaf, red stem }\end{array}$ \\
\hline Ac32 & Prk-2 & Perak & Ipoh & $04^{\circ} 77^{\prime}$ & $100^{\circ} 95^{\prime}$ & $\begin{array}{l}\text { Wild, yellow flower, wedge shaped green-red } \\
\text { leaf, red stem }\end{array}$ \\
\hline Ac33 & Prk-3 & Perak & Perak Tengah & $04^{\circ} 36^{\prime}$ & $100^{\circ} 98^{\prime}$ & $\begin{array}{l}\text { Wild, yellow flower, wedge shaped green leaf, } \\
\text { green-red stem }\end{array}$ \\
\hline Ac34 & Prk-4 & Perak & Bota Perak & $04.34^{\prime}$ & $100^{\circ} 88^{\prime}$ & $\begin{array}{l}\text { Wild, yellow flower, wedge shaped green leaf, } \\
\text { red stem }\end{array}$ \\
\hline Ac35 & Prk-5 & Perak & Teluk Intan & $04^{\circ} 02^{\prime}$ & $101^{\circ} 02^{\prime}$ & $\begin{array}{l}\text { Wild, yellow flower, wedge shaped green-red } \\
\text { leaf, red stem }\end{array}$ \\
\hline Ac36 & Png-1 & Penang & Seberang Perai & $05^{\circ} 54^{\prime}$ & $100^{\circ} 47^{\prime}$ & $\begin{array}{l}\text { Yellow flower, paddle shaped, margin } \\
\text { green-red leaf, red stem leaf }\end{array}$ \\
\hline Ac37 & Png-2 & Penang & Seberang Perai & $05^{\circ} 54^{\prime}$ & $100^{\circ} 47^{\prime}$ & $\begin{array}{l}\text { Pink flower, wedge shaped green red leaf, red } \\
\text { stem }\end{array}$ \\
\hline Ac38 & Png-3 & Penang & Seberang Perai & $05^{\circ} 54^{\prime}$ & $100^{\circ} 47^{\prime}$ & $\begin{array}{l}\text { Wild, yellow flower, wedge shaped green-red } \\
\text { leaf, red stem }\end{array}$ \\
\hline Ac44 & Pls-4 & Penang & Kuala Perlis & $06^{\circ} 23^{\prime}$ & $100^{\circ} 82^{\prime}$ & $\begin{array}{l}\text { Wild, yellow flower, wedge shaped green leaf, } \\
\text { red stem }\end{array}$ \\
\hline
\end{tabular}

salt impositions and were graded as tolerant $(\mathrm{T}=0-20 \%$ reduction), moderately tolerant ( $\mathrm{MT}=21-50 \%$ reduction), moderately susceptible ( $\mathrm{MS}=51-70 \%$ reduction), and susceptible ( $\mathrm{S} \geq 70 \%$ reduction) [21].

2.5. Statistical Analysis. All recorded data were subjected to analysis of variance using the SAS statistical software package version 9.2 [22]. Data were submitted to analysis of variance
(ANOVA) and the means were compared by Tukey's multiple range test $(P<0.05)$.

\section{Results}

Based on total dry matter reduction over control treatment a total of 13 purslane accessions (Ac7, Ac8, Ac36, Ac37, Ac23, Ac22, Ac24, Ac2, Ac3, Ac1, Ac4, Ac17, and Ac5) were selected 
from 25 accessions. Considering the above-mentioned grading classification only those accessions graded as $\mathrm{T}, \mathrm{MT}$, and MS to $30 \mathrm{dS} \mathrm{m}^{-1}$ and $40 \mathrm{dS} \mathrm{m}^{-1}$ salinity (Table 2) were selected and given chronological new accession numbers (Ac1 to Ac13) for better presentation. The other 12 accessions (graded as "S" at $30 \mathrm{dS} \mathrm{m}$ m $^{-1}$ and $40 \mathrm{dS} \mathrm{m}^{-1}$ salinity) were discarded due to very high reduction of dry matter content and their detailed analysis data have not been shown. Detailed results of selected 13 purslane accessions have been presented in Figure 1 and Tables 2-8.

3.1. Total Dry Matter Production. Dry matter (DM) contents in untreated control plants greatly varied $(P<0.001)$ among the 13 purslane accessions and ranged between 7.94 and $24.63 \mathrm{~g}$ with the highest DM content in Ac8 and the lowest in Ac5. Both of the common purslanes (Ac12 and Ac13) and 3 ornamental purslane accessions (Ac2, Ac5, and Ac10) had $<15 \mathrm{~g} /$ pot DM contents, while the remaining eight ornamental purslane accessions produced $>15 \mathrm{~g}$ dry matter/pot (Table 2). Salt treatment with $10 \mathrm{dS} \mathrm{m}^{-1}$ salinity significantly $(P<0.05)$ reduced DM contents in most accessions ranging between 2 and 19\% with the highest dry matter loss in Ac5 (18.68\%) and lowest in Ac3 (2.09\%) compared to control (Table 2). However, $10-30 \%$ reductions in DM contents were recorded at $20 \mathrm{dS} \mathrm{m}^{-1}$ salinity compared to control and over $20 \%$ reductions were recorded in Acl, Ac2, Ac5, Ac6, Ac8, and Ac12. Salt treatment with $30 \mathrm{dS} \mathrm{m}^{-1}$ salinity caused significant $(P<0.05)$ reductions $(19-45 \%)$ in DM contents in all accessions compared to control. The least affected accession was Ac7 ( $<20 \%$ reductions). With further increase in salt concentration DM contents continued to reduce in most accessions and at $40 \mathrm{dS} \mathrm{m}^{-1}$ salinity $36-67 \%$ reductions were recorded with the lowest reduction $(36.24 \%)$ in Ac10 and the highest in Ac2 (66.67\%; Table 2). The overall visual effect of salinity has been shown in Figure 1.

3.2. Plant Height. Plant height $(\mathrm{Ph})$ in untreated control plants varied very significantly $(P<0.001$; Table 3$)$ among the 13 purslane accessions and ranged between $30.27 \mathrm{~cm}$ and $66.87 \mathrm{~cm}$ with the highest plant height in Ac9 and the lowest in Ac13 (Table 4). On the other hand, NaCl-induced salinity also significantly $(P<0.001$; Table 3$)$ reduced the overall vegetative growth of purslane (Figure 1). Compared to untreated control plants, after 30 days of salt stress, plant height was highly reduced at $40 \mathrm{dS} \mathrm{m}^{-1}$ salt treatments followed by $30 \mathrm{dS} \mathrm{m}^{-1}, 20 \mathrm{dS} \mathrm{m}^{-1}$, and $10 \mathrm{dS} \mathrm{m}^{-1}$ salt treatments, respectively (Table 4). The highest plant height reduction $(>37 \%)$ was recorded at $40 \mathrm{dS} \mathrm{m}^{-1}$ salinity stress in Ac13, a common purslane, whereas the lowest plant height reduction $(<4 \%)$ was observed at $10 \mathrm{dS} \mathrm{m} \mathrm{m}^{-1}$ in Ac5, an ornamental purslane (Table 4). But interestingly $2.25 \%$ increase in plant height was recorded in $\mathrm{Acl}$ at $20 \mathrm{dS} \mathrm{m}^{-1}$ salinity level compared to control. However, $8-13 \%$ reductions $(P<0.05)$ in plant height were recorded in Acl, Ac2, Ac3, Ac8, Ac10, Ac12, and Ac13 at $10 \mathrm{dS} \mathrm{m}^{-1}$ salinity compared to control. Salt treatment with $20 \mathrm{dS} \mathrm{m}^{-1}$ salinity caused significant $(P<0.05)$ reductions (4-26\%) in plantheight in all accessions except
Acl compared to control (Table 4). Rather, about 5-31\% plant height reduction was noted at $30 \mathrm{dS} \mathrm{m}^{-1}$ salinity level compared to control plants. Plant height continued to reduce in most accessions with further increase in salt concentrations and $8-38 \%$ reductions were recorded at $40 \mathrm{dS} \mathrm{m}^{-1}$ salinity compared to control with the lowest reduction in Ac1 and Ac2 (<9\%) and the highest in Ac13 (37.33\%). On average over all accessions, $7.5,11.5,17.4$, and $21.5 \%$ reductions in plant height were recorded, respectively, at 10, 20,30, and $40 \mathrm{dS} \mathrm{m}^{-1}$ salinity, which were statistically significant $(P<0.05$; Table 4$)$.

3.3. Number of Leaves. Purslane is a leafy vegetable crop and it produces plentiful number of leaves. So, copping with salinity stress shedding of leaves is a major effect on purslane plants observed at different levels of $\mathrm{NaCl}$-induced salinity. Untreated control plants significantly $(P<0.001$; Table 5) varied in their mean number of leaves with the highest number in Acl3 (522.11) and the lowest in Ac12 (249.31; Table 6). Number of leaves in Acl and Ac8 (492.01 and 493.91) were statistically similar. Number of leaves in Ac4, Ac7, and Ac11 (465.31, 457.11, and 454.51) also were statistically similar; however, they were significantly higher $(P<0.05)$ compared to Ac3 and Ac9 (Table 6).

Salt treatment had significant $(P<0.001$; Table 5) impact on number of leaves and responses of the 13 purslane accessions to different levels of salinity were very different from each other (Table 6). The numbers of shedding of leaves were significantly increased with the increasing of salinity stress at different levels. At 10 and $20 \mathrm{dS} \mathrm{m}^{-1}$ salinity level it was observed that shedding of leaves in Ac1, Ac2, Ac4, and Ac5 was statistically similar, whereas at $30 \mathrm{dS} \mathrm{m}^{-1}$ and $40 \mathrm{dS} \mathrm{m}^{-1}$ salinity Acl, Ac2, and Ac4 were also statistically similar (Table 6). Furthermore, shedding of leaves was statistically similar in Ac6, Ac7, and Ac9 at $20 \mathrm{dS} \mathrm{m}^{-1}$ salinity, but at $30 \mathrm{dS} \mathrm{m}^{-1}$ and $40 \mathrm{dS} \mathrm{m}^{-1}$ the Acl0, Acll, and Acl3 were also statistically similar (Table 6). At $10 \mathrm{dS} \mathrm{m}^{-1}$ salinity shedding of leaves ranged between 1 and $20 \%$ with the highest number of shedding in Acl (19.02\%) and lowest in Acl1 (1.87\%). And the shedding of leaves was continued to increase significantly up to $40 \mathrm{dS} \mathrm{m}^{-1}$ salinity ranging with $4-30 \%$ at $20 \mathrm{dS} \mathrm{m}^{-1}, 7-42 \%$ at $30 \mathrm{dS} \mathrm{m}^{-1}$, and $10-47 \%$ at $40 \mathrm{dS} \mathrm{m}^{-1}$ salinity, respectively (Table 6). But in Ac5 and Ac9, all salinity levels caused significant increase in number of leaves compared to control. In Ac5 the highest increase (6.14\%) of leaf numbers was observed at $10 \mathrm{dS} \mathrm{m}^{-1}$ salinity compared to control, though the percentage of increase of leaf numbers was reduced gradually to the least increase (1.66\%) at $40 \mathrm{dS} \mathrm{m}^{-1}$ salinity. On the other hand in Ac9 the highest increase $(9.39 \%)$ of leaf numbers was found at $20 \mathrm{dS} \mathrm{m}^{-1}$ salinity followed by $8.34 \%$ increase at $30 \mathrm{dS} \mathrm{m}^{-1}$ salinity, whereas the lowest increase $(1.94 \%)$ was observed at $40 \mathrm{dS} \mathrm{m}^{-1}$ salinity followed by $2.37 \%$ at $10 \mathrm{dS} \mathrm{m}^{-1}$ salinity, respectively, compared to control by the same accession (Table 6).

3.4. Number of Flowers. The common purslane is very potential in blooming with only yellowish flower as well as 
TABLE 2: Influence of salinity on total dry matter production of purslane plants and their classification to salinity tolerance.

\begin{tabular}{|c|c|c|c|c|c|c|c|c|c|c|}
\hline \multirow[t]{2}{*}{$\begin{array}{l}\text { Aaccession } \\
\text { number }\end{array}$} & \multirow{2}{*}{$\begin{array}{l}\text { New } \\
\text { acc. } \\
\text { number }\end{array}$} & \multicolumn{5}{|c|}{$\begin{array}{l}\text { Total dry matter }(\mathrm{g}) \\
\text { Salinity level }\left(\mathrm{dS} \mathrm{m} \mathrm{m}^{-1}\right)\end{array}$} & \multicolumn{4}{|c|}{$\begin{array}{c}\text { Classification } \\
\text { Salinity level }\left(\mathrm{dS} \mathrm{m}^{-1}\right)\end{array}$} \\
\hline & & 0 & 10 & 20 & 30 & 40 & 10 & 20 & 30 & 40 \\
\hline Ac7 & $\mathrm{Acl}$ & $16.27^{\mathrm{de}}$ & $\begin{array}{l}14.13^{\mathrm{de}} \\
(13.15)\end{array}$ & $\begin{array}{l}11.48^{\mathrm{ef}} \\
(29.44)\end{array}$ & $\begin{array}{l}9.79^{\mathrm{de}} \\
(39.83)\end{array}$ & $\begin{array}{l}5.84^{\mathrm{fg}} \\
(64.11)\end{array}$ & $\mathrm{T}$ & MT & MT & MS \\
\hline Ac8 & $\mathrm{Ac} 2$ & $13.11^{\mathrm{e}-\mathrm{g}}$ & $\begin{array}{r}11.34^{\mathrm{ef}} \\
(13.5)\end{array}$ & $\begin{array}{l}9.67^{\mathrm{gh}} \\
(26.24)\end{array}$ & $\begin{array}{l}8.91^{\mathrm{d}-\mathrm{f}} \\
(32.04)\end{array}$ & $\begin{array}{l}4.37^{\mathrm{gh}} \\
(66.67)\end{array}$ & $\mathrm{T}$ & MT & MT & MS \\
\hline Ac36 & Ac3 & $23.55^{\mathrm{ab}}$ & $\begin{array}{r}20.38^{\mathrm{ab}} \\
(13.46)\end{array}$ & $\begin{array}{l}18.95^{\mathrm{b}} \\
(19.53)\end{array}$ & $\begin{array}{l}15.32^{\mathrm{a}} \\
(34.94)\end{array}$ & $\begin{array}{l}13.32^{\mathrm{a}} \\
(43.44)\end{array}$ & $\mathrm{T}$ & $\mathrm{T}$ & MT & MT \\
\hline Ac37 & Ac4 & $15.55^{\mathrm{de}}$ & $\begin{array}{r}13.97^{\mathrm{de}} \\
(10.16)\end{array}$ & $\begin{array}{l}12.51^{\mathrm{f}} \\
(19.55)\end{array}$ & $\begin{array}{l}9.95^{\mathrm{d}} \\
(36.01)\end{array}$ & $\begin{array}{c}6.23^{\mathrm{f}} \\
(59.94)\end{array}$ & $\mathrm{T}$ & $\mathrm{T}$ & MT & MS \\
\hline Ac23 & Ac5 & $7.94^{\mathrm{h}}$ & $\begin{array}{c}6.8^{\mathrm{g}} \\
(14.36)\end{array}$ & $\begin{array}{c}5.71^{\mathrm{i}} \\
(28.08)\end{array}$ & $\begin{array}{c}4.4^{\mathrm{g}} \\
(44.58)\end{array}$ & $\begin{array}{l}3.38^{\mathrm{h}} \\
(57.43)\end{array}$ & $\mathrm{T}$ & MT & MT & MT \\
\hline Ac22 & Ac6 & $20.67^{b c}$ & $\begin{array}{l}17.77^{\mathrm{bc}} \\
(14.03)\end{array}$ & $\begin{array}{l}15.38^{\mathrm{cd}} \\
(25.59)\end{array}$ & $\begin{array}{r}13.02^{\mathrm{bc}} \\
(37.01)\end{array}$ & $\begin{array}{l}9.55^{b c} \\
(53.79)\end{array}$ & $\mathrm{T}$ & MT & MT & MT \\
\hline Ac24 & Ac7 & $15.91^{\mathrm{de}}$ & $\begin{array}{l}14.17^{\mathrm{de}} \\
(10.93)\end{array}$ & $\begin{array}{l}12.9^{\text {ef }} \\
(18.92)\end{array}$ & $\begin{array}{l}12.75^{\mathrm{c}} \\
(19.86)\end{array}$ & $\begin{array}{l}7.98^{\mathrm{c}-\mathrm{e}} \\
(49.84)\end{array}$ & $\mathrm{T}$ & $\mathrm{T}$ & $\mathrm{T}$ & MT \\
\hline Ac2 & Ac8 & $24.63^{\mathrm{a}}$ & $\begin{array}{l}21.66^{\mathrm{a}} \\
(12.06)\end{array}$ & $\begin{array}{l}17.57^{\mathrm{bc}} \\
(28.66)\end{array}$ & $\begin{array}{l}15.16^{\mathrm{ab}} \\
(38.45)\end{array}$ & $\begin{array}{l}8.92^{\mathrm{cd}} \\
(63.78)\end{array}$ & $\mathrm{T}$ & MT & MT & MS \\
\hline Ac3 & Ac9 & $23.9^{\mathrm{ab}}$ & $\begin{array}{l}23.4^{\mathrm{a}} \\
(2.09)\end{array}$ & $\begin{array}{c}21.3^{\mathrm{a}} \\
(10.87)\end{array}$ & $\begin{array}{l}15.5^{\mathrm{a}} \\
(35.15)\end{array}$ & $\begin{array}{l}13.48^{\mathrm{a}} \\
(43.59)\end{array}$ & $\mathrm{T}$ & $\mathrm{T}$ & $\mathrm{T}$ & MT \\
\hline Acl & Ac10 & $10.1^{\text {gh }}$ & $\begin{array}{c}8.6^{\mathrm{fg}} \\
(14.85)\end{array}$ & $\begin{array}{l}8.62^{\mathrm{h}} \\
(14.65)\end{array}$ & $\begin{array}{c}7.72^{\mathrm{ef}} \\
(23.56)\end{array}$ & $\begin{array}{l}6.44^{\mathrm{ef}} \\
(36.24)\end{array}$ & $\mathrm{T}$ & $\mathrm{T}$ & MT & MT \\
\hline Ac4 & Acll & $18.84^{\mathrm{cd}}$ & $\begin{array}{l}16.11^{\text {cd }} \\
(14.49)\end{array}$ & $\begin{array}{l}15.1^{\mathrm{de}} \\
(19.85)\end{array}$ & $\begin{array}{c}13.43^{\mathrm{a}-\mathrm{c}} \\
(28.72)\end{array}$ & $\begin{array}{l}10.66^{\mathrm{b}} \\
(43.42)\end{array}$ & $\mathrm{T}$ & $\mathrm{T}$ & MT & MT \\
\hline Ac17 & Acl2 & $14.41^{\mathrm{ef}}$ & $\begin{array}{c}13.09^{\mathrm{de}} \\
(9.16)\end{array}$ & $\begin{array}{c}10.72^{\mathrm{f}-\mathrm{h}} \\
(25.61)\end{array}$ & $\begin{array}{l}9.46^{\mathrm{de}} \\
(34.35)\end{array}$ & $\begin{array}{l}7.33^{\mathrm{d}-\mathrm{f}} \\
(42.19)\end{array}$ & $\mathrm{T}$ & MT & MT & MT \\
\hline Ac5 & Ac13 & $11.67^{\mathrm{fg}}$ & $\begin{array}{l}9.49^{\mathrm{gh}} \\
(18.68) \\
\end{array}$ & $\begin{array}{l}9.35^{\mathrm{gh}} \\
(19.88) \\
\end{array}$ & $\begin{array}{c}7.41^{\mathrm{f}} \\
(38.51) \\
\end{array}$ & $\begin{array}{l}4.04^{\mathrm{h}} \\
(58.17) \\
\end{array}$ & $\mathrm{T}$ & $\mathrm{T}$ & MT & MS \\
\hline Ac9 & & 13.44 & 8.32 & 4.11 & 2.01 & 1.8 & MT & MS & S & $S$ \\
\hline Ac25 & & 10.88 & 7.91 & 3.38 & 2.11 & 1.62 & MT & MS & S & $S$ \\
\hline Ac10 & & 16.04 & 10.13 & 4.21 & 2.78 & 2.01 & MT & MS & S & $S$ \\
\hline Ac38 & & 11.11 & 7.48 & 4.11 & 2.21 & 1.54 & MT & MS & S & $\mathrm{S}$ \\
\hline Ac32 & All are & 19.23 & 13.09 & 7.21 & 3.33 & 2.07 & MT & MS & $S$ & $\mathrm{~S}$ \\
\hline Ac31 & discarded & 17.65 & 12.26 & 8.48 & 3.26 & 2.19 & MT & MT & S & S \\
\hline Ac27 & susceptible & 21.02 & 14.65 & 8.33 & 2.38 & 1.89 & MT & MS & $S$ & $S$ \\
\hline Ac12 & to & 13.21 & 7.21 & 5.03 & 2.45 & 1.67 & MT & MS & S & $S$ \\
\hline Ac33 & salinity & 22.04 & 15.28 & 7.11 & 3.21 & 2.06 & MT & MS & S & $S$ \\
\hline Ac34 & & 11.89 & 8.24 & 4.18 & 2.03 & 1.56 & $\mathrm{MT}$ & MS & $S$ & $S$ \\
\hline Ac35 & & 8.2 & 4.11 & 2.53 & 1.98 & 1.4 & MT & MS & S & $S$ \\
\hline Ac44 & & 10.49 & 6.65 & 3.12 & 1.98 & 1.29 & MT & MS & $S$ & $\mathrm{~S}$ \\
\hline
\end{tabular}

Values followed by different letters differ significantly according to Tukey's multiple range tests at $P<0.05$. Values in the parentheses indicate percent compared to the untreated control $\left(0 \mathrm{dS} \mathrm{m}^{-1}\right)$ plants.

TABLE 3: ANOVA table for plant height with salinity treatments.

\begin{tabular}{|c|c|c|c|c|c|}
\hline Source & DF & ANOVA SS & Mean square & $F$ value & $\operatorname{Pr}>F$ \\
\hline Accessions & 12 & 13730.12800 & 1144.17733 & 2087.86 & $<0.0001$ \\
\hline $\mathrm{NaCl}$ & 4 & 2370.54851 & 592.63713 & 1081.42 & $<0.0001$ \\
\hline blk & 2 & 5.00449 & 2.50224 & 4.57 & 0.0121 \\
\hline Accessions $* \mathrm{NaCl}$ & 48 & 725.39815 & 15.11246 & 27.58 & $<0.0001$ \\
\hline
\end{tabular}


TABLE 4: Effect of salinity on plant height of 13 salt treated purslane accessions.

\begin{tabular}{|c|c|c|c|c|c|}
\hline \multirow[t]{2}{*}{$\begin{array}{l}\text { Accession } \\
\text { number }\end{array}$} & \multicolumn{5}{|c|}{$\begin{array}{c}\text { Plant height }(\mathrm{cm}) \\
\text { Salinity level }\left(\mathrm{dS} \mathrm{m}^{-1}\right)\end{array}$} \\
\hline & 0 & 10 & 20 & 30 & 40 \\
\hline $\mathrm{Acl}$ & $39.97 \pm 1.40^{\mathrm{ab}}$ & $\begin{array}{c}35.17 \pm 1.60^{\mathrm{h}} \\
(12.01)\end{array}$ & $\begin{array}{c}40.87 \pm 1.60^{\mathrm{e}} \\
(-2.25)\end{array}$ & $\begin{array}{l}33.57 \pm 1.40^{\mathrm{f}} \\
(16.01)\end{array}$ & $\begin{array}{c}36.57 \pm 1.30^{\mathrm{ef}} \\
(8.51)\end{array}$ \\
\hline Ac2 & $39.67 \pm 3.30^{\mathrm{ab}}$ & $\begin{array}{c}36.07 \pm 0.27^{\mathrm{h}} \\
(9.07)\end{array}$ & $\begin{array}{c}34.27 \pm 0.28^{g} \\
(13.61)\end{array}$ & $\begin{array}{c}37.37 \pm 0.37^{\mathrm{e}} \\
(5.79)\end{array}$ & $\begin{array}{c}36.47 \pm 0.18^{\text {ef }} \\
(8.07)\end{array}$ \\
\hline Ac3 & $42.67 \pm 0.55^{\mathrm{de}}$ & $\begin{array}{l}38.97 \pm 0.21^{\mathrm{g}} \\
\quad(8.67)\end{array}$ & $\begin{array}{c}38.57 \pm 0.39^{\mathrm{f}} \\
(9.61)\end{array}$ & $\begin{array}{c}37.67 \pm 0.31^{\mathrm{e}} \\
(11.72)\end{array}$ & $\begin{array}{c}34.57 \pm 0.43^{\mathrm{f}} \\
(18.98)\end{array}$ \\
\hline Ac4 & $44.97 \pm 0.27^{\mathrm{ab}}$ & $\begin{array}{c}42.37 \pm 0.28^{\mathrm{f}} \\
(5.78)\end{array}$ & $\begin{array}{c}39.57 \pm 0.11^{\mathrm{ef}} \\
(12.01)\end{array}$ & $\begin{array}{c}38.27 \pm 0.28^{\mathrm{e}} \\
(14.89)\end{array}$ & $\begin{array}{c}37.37 \pm 0.39 \\
(16.9)\end{array}$ \\
\hline Ac5 & $39.57 \pm 0.24^{\mathrm{cd}}$ & $\begin{array}{c}38.17 \pm 0.21^{g} \\
(3.54)\end{array}$ & $\begin{array}{c}37.87 \pm 0.07^{\mathrm{f}} \\
(4.29)\end{array}$ & $\begin{array}{c}36.67 \pm 0.39^{\mathrm{e}} \\
(7.33)\end{array}$ & $\begin{array}{c}34.27 \pm 0.19^{\mathrm{f}} \\
(13.39)\end{array}$ \\
\hline Ac6 & $56.47 \pm 0.21^{b c}$ & $\begin{array}{l}53.57 \pm 0.23^{c} \\
(5.14)\end{array}$ & $\begin{array}{c}50.27 \pm 0.18^{b} \\
\quad(10.98)\end{array}$ & $\begin{array}{c}47.07 \pm 0.31^{\mathrm{b}} \\
(16.65)\end{array}$ & $\begin{array}{c}43.27 \pm 0.21^{\mathrm{b}} \\
(23.38)\end{array}$ \\
\hline Ac7 & $53.27 \pm 0.27^{\mathrm{ab}}$ & $\begin{array}{c}49.27 \pm 0.25^{\mathrm{d}} \\
(7.51)\end{array}$ & $\begin{array}{c}46.67 \pm 0.31^{c} \\
(12.38)\end{array}$ & $\begin{array}{c}43.57 \pm 0.35^{\mathrm{c}} \\
(18.21)\end{array}$ & $\begin{array}{c}40.07 \pm 0.16^{\mathrm{c}} \\
(24.78)\end{array}$ \\
\hline Ac8 & $49.77 \pm 0.23^{\mathrm{ab}}$ & $\begin{array}{c}45.07 \pm 0.39^{\mathrm{e}} \\
(9.44)\end{array}$ & $\begin{array}{c}44.37 \pm 0.27^{\mathrm{d}} \\
(10.84)\end{array}$ & $\begin{array}{c}42.67 \pm 0.31^{\mathrm{cd}} \\
(14.27)\end{array}$ & $\begin{array}{c}40.97 \pm 0.29^{\mathrm{bc}} \\
(17.68)\end{array}$ \\
\hline Ac9 & $66.87 \pm 0.19^{\mathrm{de}}$ & $\begin{array}{c}64.27 \pm 0.27^{\mathrm{a}} \\
(3.89)\end{array}$ & $\begin{array}{c}60.67 \pm 0.27^{\mathrm{a}} \\
(9.27)\end{array}$ & $\begin{array}{c}54.47 \pm 0.21^{\mathrm{a}} \\
(18.54)\end{array}$ & $\begin{array}{c}50.17 \pm 0.18^{\mathrm{a}} \\
(24.97)\end{array}$ \\
\hline Ac10 & $56.07 \pm 0.29^{\mathrm{d}}$ & $\begin{array}{c}51.27 \pm 0.24^{\mathrm{c}} \\
(8.56)\end{array}$ & $\begin{array}{c}48.67 \pm 0.33^{b} \\
(13.19)\end{array}$ & $\begin{array}{c}41.17 \pm 0.17^{\mathrm{d}} \\
(26.57)\end{array}$ & $\begin{array}{c}39.67 \pm 0.33^{\mathrm{cd}} \\
(29.25)\end{array}$ \\
\hline Ac11 & $40.67 \pm 0.28^{\mathrm{ab}}$ & $\begin{array}{c}38.47 \pm 0.13^{\mathrm{g}} \\
(5.41)\end{array}$ & $\begin{array}{c}35.27 \pm 0.21^{\mathrm{g}} \\
\quad(13.28)\end{array}$ & $\begin{array}{c}33.77 \pm 0.19^{f} \\
(16.97)\end{array}$ & $\begin{array}{c}30.57 \pm 0.13^{\mathrm{g}} \\
(24.83)\end{array}$ \\
\hline Ac12 & $42.17 \pm 0.99^{\mathrm{e}}$ & $\begin{array}{c}38.07 \pm 1.09^{g} \\
(9.72)\end{array}$ & $\begin{array}{c}33.57 \pm 0.84^{\mathrm{g}} \\
(20.39)\end{array}$ & $\begin{array}{c}30.27 \pm 1.19^{\mathrm{g}} \\
(28.22)\end{array}$ & $\begin{array}{c}29.67 \pm 1.13^{\mathrm{g}} \\
(29.64)\end{array}$ \\
\hline Ac13 & $30.27 \pm 0.94^{\mathrm{a}}$ & $\begin{array}{c}26.47 \pm 0.91^{\mathrm{i}} \\
(12.55)\end{array}$ & $\begin{array}{c}22.57 \pm 0.89^{\mathrm{h}} \\
(25.44)\end{array}$ & $\begin{array}{c}21.10 \pm 0.52^{\mathrm{h}} \\
(30.29)\end{array}$ & $\begin{array}{c}18.97 \pm 1.97^{\mathrm{h}} \\
(37.33)\end{array}$ \\
\hline Mean & $46.34 \pm 9.72^{\mathrm{a}}$ & $\begin{array}{c}42.86 \pm 9.76^{\mathrm{b}} \\
(7.5)\end{array}$ & $\begin{array}{c}41.02 \pm 9.42^{c} \\
(11.5)\end{array}$ & $\begin{array}{c}38.28 \pm 8.17^{\mathrm{d}} \\
(17.4)\end{array}$ & $\begin{array}{c}36.35 \pm 7.49^{\mathrm{e}} \\
(21.54)\end{array}$ \\
\hline
\end{tabular}

Mean values with \pm SE followed by different letters differ significantly according to Tukey's multiple range tests at $P<0.05$. Values in the parentheses indicate percent compared to the untreated control $\left(0 \mathrm{dS} \mathrm{m}^{-1}\right)$ plants.

seed production, whereas the ornamental purslane produces different colorful and attractive flowers. Salinity had a great bad impact on plants reproductive stage. Stopped blooming or shedding of flower is very common among all other morphological characteristics due to salinity stress.

Mean number of flowers in untreated control plants also significantly varied $(P<0.001$; Table 7$)$ between purslane accessions with the highest number in Ac12 (52.36) followed by Ac13 (46.5) and the lowest in Ac8 (4.32) followed by Ac9 and Ac11 (7.67 and 12.23). But the flower numbers in Ac6 and Ac7 were statistically similar (33.46 and 33.26; Table 8).

Salt treatments also significantly $(P<0.001$; Table 7$)$ impacted number of flowers in purslane plants. Treatment with $10 \mathrm{dS} \mathrm{m}^{-1}$ salinity, the Ac4 and Ac5 (Table 8), Ac10 and Ac11 (Table 8) were statistically similar (Table 8). Further at $20 \mathrm{dS} \mathrm{m}^{-1}$ salinity the Ac2 and Ac4 (Table 8) and Ac10 and Acl1 (Table 8) were also statistically similar. Statistically similar results were also observed in Ac1, Ac2, and Ac4 (Table 8), Ac8 and Ac9 (Table 8), and Ac10 and Acl1 (Table 8) at the highest $40 \mathrm{dS} \mathrm{m}^{-1}$ salinity. Flower reduction ranged between 5 and $69 \%$ at $10 \mathrm{dS} \mathrm{m}^{-1}$ with the highest number
(68.18\%) in Ac3 and the lowest (5.38\%) in Ac7 (Table 8). At $20 \mathrm{dS} \mathrm{m}^{-1}$ salinity flower reduction observed the highest in Ac9 (83.71\%) and the lowest in Ac5 (25.82\%). Further, at $30 \mathrm{dS} \mathrm{m}^{-1}$ salinity flower reduction varied between 33 and $91 \%$ with the highest reduction (90.82\%) in Acl and the lowest reduction (33.25\%) observed in Ac7 (Table 8). Flower number reduction was continued significantly up to the highest level of salinity and at $40 \mathrm{dS} \mathrm{m}^{-1}$ salinity the Acl, Ac4, Ac9, Ac10, Ac11, and Ac13 fully stopped (100\%) flowering compared to control (Table 8).

\section{Discussion}

As we mentioned earlier due to high sensitivity to salinity and dry matter reduction at $30 \mathrm{dS} \mathrm{m}^{-1}$ and $40 \mathrm{dS} \mathrm{m}^{-1}$ salinity compared to untreated control ( $0 \mathrm{dS} \mathrm{m}^{-1}$ salinity) 13 purslane accessions (11 ornamental and 2 common purslanes) were screened out and the remaining 12 purslane accessions were discarded from detailed data presentation and discussions, that is, all thorough the paper only we have presented data of these 13 selected purslane accessions and discussed properly. 

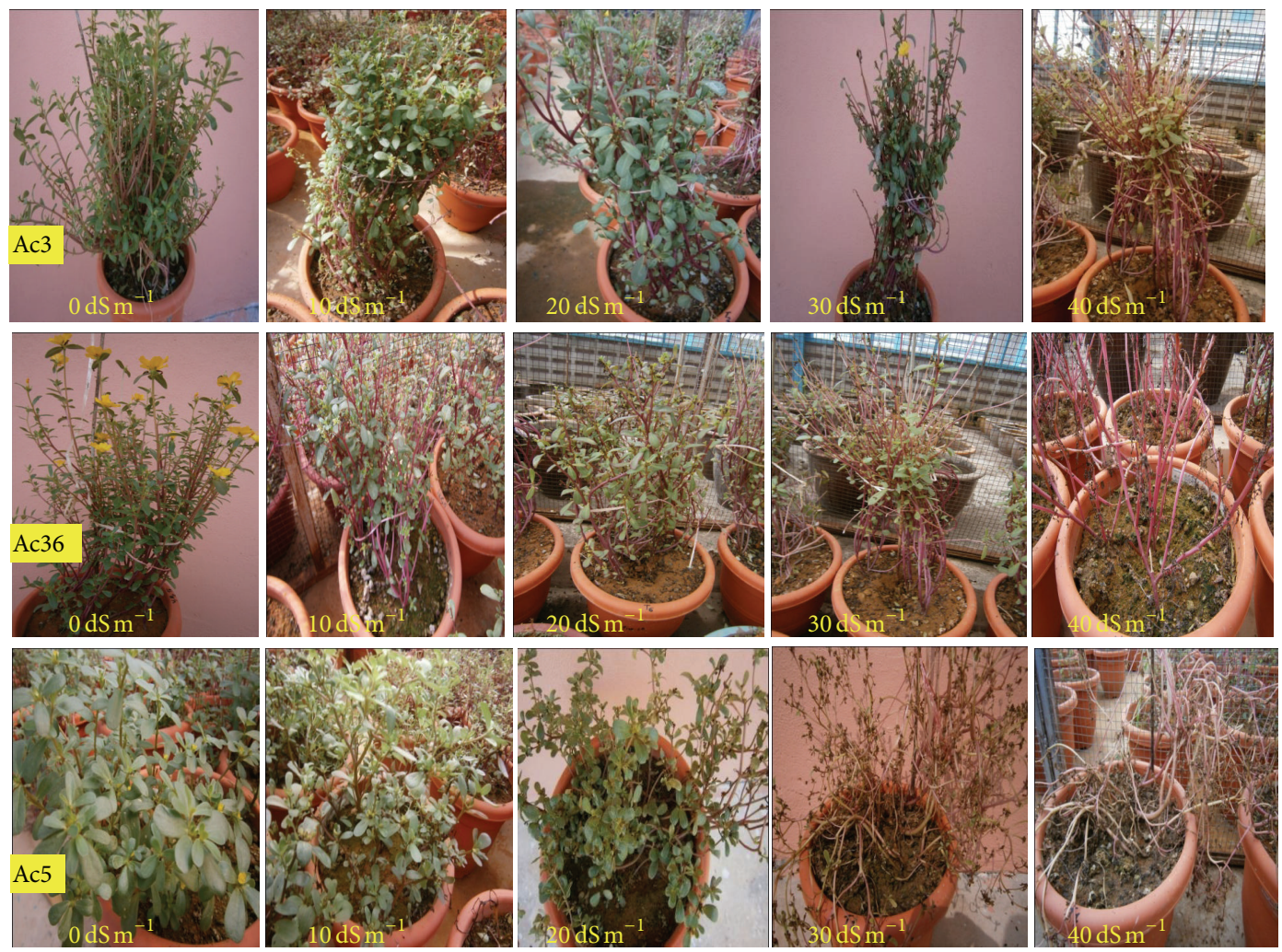

FIGURE 1: Effect of salinity on different purslane accessions.

However, the analysis results showed that untreated control plants greatly varied in their performance of all the recorded parameters. Salt treatment also significantly influenced all traits investigated in this study. But the responses of the 13 purslane accessions to salt treatment were very different from each other and followed a significant reduction trend from lowest to the highest salinity inductions, which indicates a vast diversity among the purslane accessions collected from different locations in Western Peninsular Malaysia.

The dry matter contents among all 13 untreated purslane accessions ranged from about $7 \mathrm{~g}$ to about $24 \mathrm{~g}$ (about 3-fold from lowest to the highest; Table 2) where Ac3, Ac8, and Ac9 were statistically similar for dry matter production $(\sim 24 \mathrm{~g})$. On the other hand, Ac6 and Acll were also found similar $(\sim 19 \mathrm{~g})$ for dry matter production but greatly varied in other parameters. Furthermore, two common purslanes (Ac12 and Ac13) were statistically different in their dry matter contents (Table 2). On the other hand, plant height ranged from about $30 \mathrm{~cm}$ to $67 \mathrm{~cm}$ (about 2-fold from lowest to highest;Table 4). The number of leaves ranged from 249 to 523 (about 2-fold from lowest to the highest, Table 6) and the number of flowers ranged from 4 to 53 (about 14-fold from lowest to the highest, Table 8).

Salt treatment also had significant impacts on plant height, number of leaves, number of flowers, and dry matter content of the 13 purslane accessions. However, responses of the individual accessions were very different from each other.
One general trait was that treatment with lowest $\left(10 \mathrm{dS} \mathrm{m}^{-1}\right)$ to the highest $\left(40 \mathrm{dS} \mathrm{m}^{-1}\right)$ salinity caused significant reductions in plant height, number of leaves, number of flowers, and dry matter content.

Dry matter contents in salt treated 13 purslane accessions showed very high significant variation. From the beginning $\left(10 \mathrm{dS} \mathrm{m}^{-1}\right)$ to the second phase $\left(20 \mathrm{dS} \mathrm{m}^{-1}\right)$ increasing of salinity, the 2-fold decreasing of dry matter content was recorded in Ac1, Ac2, Ac4, Ac5, and Ac8, whereas >4-fold decrease was observed in Ac9 (Table 2). The decrease of dry matter content was less than 1-fold for other purslane accessions in that same saline condition. On the other hand, due to the increase of salinity from $20 \mathrm{dS} \mathrm{m}^{-1}$ to $30 \mathrm{dS} \mathrm{m}^{-1}$ and $30 \mathrm{dS} \mathrm{m}^{-1}$ to $40 \mathrm{dS} \mathrm{m}^{-1}$ salinity, the decreasing of dry matter content was comparatively lower than the previous state, maybe due to the increase of tolerance mechanisms among purslane accessions. Overall reductions of dry matter contents at both of this salinity phases were less than 2fold for all the 13 purslane accessions except Ac2 and Ac7 (Table 2). The same findings of reduction of dry matter contents due to salinity stress have been described by many scientists globally in many crops. More than $70 \%$ reduction in shoot dry mass content has been reported in maize by Eker et al. [23] at $250 \mathrm{mM}$ salinity. A highly significant $(P \leq$ $0.0001)$ decrease in both shoot and root dry matter contents was observed in sugar beet cultivars at $350 \mathrm{mM}$ salinity [24]. Dry matter content of mature tomato fruits was found to be 
TABLE 5: ANOVA table for number of leaves with salinity treatments.

\begin{tabular}{lccccc}
\hline Source & DF & ANOVA SS & Mean square & $F$ value & Pr $>F$ \\
\hline Accessions & 12 & 736603.2666 & 61383.6055 & 113.57 & 139.87 \\
$\mathrm{NaCl}$ & 4 & 302386.3625 & 75596.5906 & $<0.0001$ \\
blk & 2 & 2068.5255 & 1034.2627 & 1.91 & 0.0001 \\
Accessions $* \mathrm{NaCl}$ & 48 & 184583.3601 & 3845.4867 & 7.12 & $<0.0001$ \\
\hline
\end{tabular}

TABLE 6: Effect of salinity on number of leaves of 13 salt treated purslane accessions.

\begin{tabular}{|c|c|c|c|c|c|}
\hline \multirow[t]{2}{*}{$\begin{array}{l}\text { Accession } \\
\text { number }\end{array}$} & \multicolumn{5}{|c|}{$\begin{array}{c}\text { Number of leaves } \\
\text { Salinity level }\left(\mathrm{dS} \mathrm{m}^{-1}\right)\end{array}$} \\
\hline & 0 & 10 & 20 & 30 & 40 \\
\hline Acl & $492.01 \pm 46.41^{\mathrm{ab}}$ & $\begin{array}{c}398.41 \pm 32.59^{\mathrm{bc}} \\
(19.02)\end{array}$ & $\begin{array}{c}348.11 \pm 35.81^{\mathrm{c}} \\
(29.25)\end{array}$ & $\begin{array}{c}317.41 \pm 12.47^{\mathrm{b}} \\
(35.49)\end{array}$ & $\begin{array}{c}300.32 \pm 21.79^{\text {cd }} \\
(38.96)\end{array}$ \\
\hline Ac2 & $467.91 \pm 12.93^{\mathrm{ab}}$ & $\begin{array}{c}380.51 \pm 18.55^{\mathrm{cd}} \\
(18.68)\end{array}$ & $\begin{array}{c}329.11 \pm 26.93^{c} \\
(29.66)\end{array}$ & $\begin{array}{c}318.51 \pm 23.59^{b} \\
\quad(31.93)\end{array}$ & $\begin{array}{c}300.01 \pm 18.33^{\mathrm{cd}} \\
(35.88)\end{array}$ \\
\hline Ac3 & $317.51 \pm 23.37^{\mathrm{de}}$ & $\begin{array}{c}280.91 \pm 12.72^{\text {ed }} \\
(11.53)\end{array}$ & $\begin{array}{c}227.51 \pm 24.53^{\mathrm{d}} \\
(28.35)\end{array}$ & $\begin{array}{c}187.08 \pm 72.59^{c} \\
(41.08)\end{array}$ & $\begin{array}{c}208.01 \pm 27.34^{\mathrm{ef}} \\
(34.49)\end{array}$ \\
\hline Ac4 & $456.31 \pm 42.78^{\mathrm{ab}}$ & $\begin{array}{c}384.21 \pm 27.44^{\mathrm{cd}} \\
(15.81)\end{array}$ & $\begin{array}{c}370.01 \pm 20.33^{b c} \\
(18.91)\end{array}$ & $\begin{array}{c}316.61 \pm 11.59^{b} \\
(30.62)\end{array}$ & $\begin{array}{c}288.41 \pm 32.01^{\mathrm{cd}} \\
(36.79)\end{array}$ \\
\hline Ac5 & $372.51 \pm 18.32^{\mathrm{cd}}$ & $\begin{array}{c}384.21 \pm 15.92^{\mathrm{cd}} \\
(-6.14)\end{array}$ & $\begin{array}{c}378.41 \pm 16.48^{\mathrm{bc}} \\
(-3.97)\end{array}$ & $\begin{array}{c}387.31 \pm 12.71^{\mathrm{ab}} \\
\quad(-3.14)\end{array}$ & $\begin{array}{c}395.41 \pm 16.58^{\mathrm{a}} \\
(-1.66)\end{array}$ \\
\hline Ac6 & $423.51 \pm 14.89^{\mathrm{bc}}$ & $\begin{array}{c}394.41 \pm 16.42^{\mathrm{bc}} \\
(6.87)\end{array}$ & $\begin{array}{c}378.51 \pm 15.62^{\mathrm{bc}} \\
(10.63)\end{array}$ & $\begin{array}{c}376.41 \pm 21.45^{\mathrm{ab}} \\
(11.12)\end{array}$ & $\begin{array}{c}377.91 \pm 27.49^{\mathrm{ab}} \\
(10.77)\end{array}$ \\
\hline Ac7 & $457.11 \pm 24.15^{\mathrm{ab}}$ & $\begin{array}{c}410.91 \pm 20.55^{\mathrm{bc}} \\
(10.11)\end{array}$ & $\begin{array}{c}380.01 \pm 22.57^{b c} \\
(16.87)\end{array}$ & $\begin{array}{c}355.41 \pm 8.45^{\mathrm{ab}} \\
(22.25)\end{array}$ & $\begin{array}{c}316.41 \pm 21.42^{\mathrm{b}-\mathrm{d}} \\
(30.78)\end{array}$ \\
\hline Ac8 & $493.91 \pm 22.42^{\mathrm{ab}}$ & $\begin{array}{c}477.81 \pm 28.42^{\mathrm{a}} \\
\quad(3.26)\end{array}$ & $\begin{array}{c}456.41 \pm 23.42^{\mathrm{a}} \\
(7.59)\end{array}$ & $\begin{array}{c}416.01 \pm 15.69^{\mathrm{a}} \\
(15.77)\end{array}$ & $\begin{array}{c}398.21 \pm 16.31^{\mathrm{a}} \\
(19.38)\end{array}$ \\
\hline Ac9 & $320.31 \pm 11.18^{\mathrm{de}}$ & $\begin{array}{c}327.91 \pm 16.96^{\mathrm{de}} \\
(-2.37)\end{array}$ & $\begin{array}{c}350.41 \pm 13.46^{\mathrm{c}} \\
(-9.39)\end{array}$ & $\begin{array}{c}326.51 \pm 27.02^{\mathrm{b}} \\
(-1.94)\end{array}$ & $\begin{array}{c}347.01 \pm 17.85^{\mathrm{a}-\mathrm{c}} \\
(-8.34)\end{array}$ \\
\hline Ac10 & $339.31 \pm 19.18^{\mathrm{d}}$ & $\begin{array}{c}330.11 \pm 10.99^{\mathrm{de}} \\
(2.71)\end{array}$ & $\begin{array}{c}323.41 \pm 13.54^{\mathrm{c}} \\
(4.69)\end{array}$ & $\begin{array}{c}315.01 \pm 18.51^{\mathrm{b}} \\
(7.16)\end{array}$ & $\begin{array}{c}300.11 \pm 23.16^{\mathrm{cd}} \\
(11.55)\end{array}$ \\
\hline Acll & $454.51 \pm 22.43^{\mathrm{ab}}$ & $\begin{array}{c}446.01 \pm 15.63^{\mathrm{ab}} \\
(1.87)\end{array}$ & $\begin{array}{c}420.01 \pm 13.33^{\mathrm{ab}} \\
(7.59)\end{array}$ & $\begin{array}{c}356.61 \pm 38.25^{\mathrm{ab}} \\
(21.54)\end{array}$ & $\begin{array}{c}255.11 \pm 20.92^{\mathrm{de}} \\
(43.87)\end{array}$ \\
\hline Ac12 & $249.31 \pm 15.73^{\mathrm{e}}$ & $\begin{array}{c}240.61 \pm 13.93^{\mathrm{f}} \\
(3.49)\end{array}$ & $\begin{array}{c}222.41 \pm 18.49^{\mathrm{d}} \\
(10.79)\end{array}$ & $\begin{array}{c}168.21 \pm 14.24^{\mathrm{c}} \\
(32.53)\end{array}$ & $\begin{array}{c}163.11 \pm 23.02^{\mathrm{f}} \\
(34.58)\end{array}$ \\
\hline Ac13 & $522.11 \pm 17.19^{\mathrm{a}}$ & $\begin{array}{c}428.21 \pm 14.97^{\mathrm{ab}} \\
(17.98)\end{array}$ & $\begin{array}{c}385.84 \pm 14.48^{\mathrm{bc}} \\
(26.09)\end{array}$ & $\begin{array}{c}318.19 \pm 18.07^{\mathrm{b}} \\
(39.06)\end{array}$ & $\begin{array}{c}280.11 \pm 25.07^{\mathrm{cd}} \\
(46.35)\end{array}$ \\
\hline Mean & $412.79 \pm 94.13^{\mathrm{a}}$ & $\begin{array}{c}376.57 \pm 66.2^{\mathrm{b}} \\
\quad(8.78)\end{array}$ & $\begin{array}{c}352.24 \pm 66.69^{c} \\
(14.67)\end{array}$ & $\begin{array}{c}319.71 \pm 70.66^{\mathrm{d}} \\
(28.48)\end{array}$ & $\begin{array}{c}301.01 \pm 67.13^{\mathrm{e}} \\
(27.46)\end{array}$ \\
\hline
\end{tabular}

Mean values with \pm SE followed by different letters differ significantly according to Tukey's multiple range tests at $P<0.05$. Values in the parentheses indicate percent compared to the untreated control $\left(0 \mathrm{dS} \mathrm{m}^{-1}\right)$ plants. "-" indicates $\%$ increase due to salinity stress.

decreased with application of elevated salt treatments $[25,26]$. The same results also have been reported in several crops in radish [27], in Kyllingia peruviana L. [28], in turfgrass species [17], in Bruguiera gymnorrhiza L. [29], in Pennisetum glaucum L. [11], and in Brassica campestris L. [30].

In spite of the reduction of fresh and dry matter contents many studies have also reported the positive effect of salinity stress on biomass production. Dantus et al. [31] stated the increased total biomass production in cowpea (Vigna unguiculata L.) seedling treated by $10 \mathrm{mM}$ of sodium chloride solution. In another study, Orak and Ateş [32] and Nedjimi et al. [33] reported the increase in fresh and dry weight of shoot and root systems of common vetch (Vicia sativa L.) and
Atriplex halimus L. plants treated with lower concentrations of $\mathrm{NaCl}$. The increase in fresh weight may be due to the plant's ability to increase the size of its sap vacuoles, which allows for the accumulation of a lot of water, and this in turn dissolves salt ions that have amassed and leads to the subsequent augment in fresh weight [4].

Reduction in plant height is very common in many plants due to different salinity stress reported in several research articles. Though purslane is already proved as moderately tolerant to salinity, this is the first time we have observed the significant reduction in plant height at the highest salinity levels (Table 4). This result is in agreement with Yakubu et al. [34] who reported that the effect of salinity on growth of 
TABLE 7: ANOVA table for number of flowers with salinity treatments.

\begin{tabular}{|c|c|c|c|c|c|}
\hline Source & DF & ANOVA SS & Mean square & $F$ value & $\operatorname{Pr}>F$ \\
\hline Accessions & 12 & 11181.42225 & 931.78519 & 2058.49 & $<0.0001$ \\
\hline $\mathrm{NaCl}$ & 4 & 14251.59393 & 3562.89848 & 7871.12 & $<0.0001$ \\
\hline blk & 2 & 2.77409 & 1.38704 & 3.06 & 0.0501 \\
\hline Accessions $* \mathrm{NaCl}$ & 48 & 5435.35492 & 113.23656 & 250.16 & $<0.0001$ \\
\hline
\end{tabular}

TABLE 8: Effect of salinity on number of flowers of 13 salt treated purslane accessions.

\begin{tabular}{|c|c|c|c|c|c|}
\hline \multirow{2}{*}{$\begin{array}{l}\text { Accession } \\
\text { number }\end{array}$} & \multicolumn{5}{|c|}{$\begin{array}{c}\text { Number of flowers } \\
\text { Salinity level }\left(\mathrm{dS} \mathrm{m}^{-1}\right)\end{array}$} \\
\hline & 0 & 10 & 20 & 30 & 40 \\
\hline Acl & $23.54 \pm 0.69^{g}$ & $\begin{array}{l}15.42 \pm 5.01^{\mathrm{f}} \\
(34.49)\end{array}$ & $\begin{array}{c}6.12 \pm 0.80^{\mathrm{g}} \\
(74.01)\end{array}$ & $\begin{array}{l}2.16 \pm 0.34^{\mathrm{h}} \\
(90.82)\end{array}$ & $\begin{array}{c}0^{\mathrm{f}} \\
(100)\end{array}$ \\
\hline Ac2 & $35.22 \pm 0.69^{c}$ & $\begin{array}{c}28.52 \pm 0.40^{c} \\
(19.02)\end{array}$ & $\begin{array}{l}16.78 \pm 0.42^{e} \\
\quad(52.36)\end{array}$ & $\begin{array}{c}12.11 \pm 0.35^{\mathrm{d}} \\
(65.62)\end{array}$ & $\begin{array}{l}0.14 \pm 0.19^{\mathrm{f}} \\
(99.6)\end{array}$ \\
\hline Ac3 & $22.66 \pm 0.31^{\mathrm{g}}$ & $\begin{array}{c}7.21 \pm 0.16^{\mathrm{h}} \\
\quad(68.18)\end{array}$ & $\begin{array}{c}4.28 \pm 0.22^{\mathrm{h}} \\
(81.11)\end{array}$ & $\begin{array}{c}6.77 \pm 0.23^{\mathrm{f}} \\
(70.12)\end{array}$ & $\begin{array}{l}1.27 \pm 0.23^{\mathrm{e}} \\
\quad(94.39)\end{array}$ \\
\hline Ac4 & $32.17 \pm 0.17^{\mathrm{e}}$ & $\begin{array}{c}26.02 \pm 0.26^{\mathrm{d}} \\
(19.12)\end{array}$ & $\begin{array}{l}17.49 \pm 0.27^{\mathrm{e}} \\
(45.63)\end{array}$ & $\begin{array}{c}6.69 \pm 0.31^{\mathrm{e}} \\
(79.2)\end{array}$ & $\begin{array}{c}0^{\mathrm{f}} \\
(100)\end{array}$ \\
\hline Ac5 & $27.19 \pm 0.21^{\mathrm{f}}$ & $\begin{array}{c}25.71 \pm 0.35^{\mathrm{d}} \\
(5.44)\end{array}$ & $\begin{array}{l}20.17 \pm 0.21^{c} \\
(25.82)\end{array}$ & $\begin{array}{c}15.26 \pm 0.16^{\mathrm{b}} \\
(43.88)\end{array}$ & $\begin{array}{c}10.03 \pm 0.27^{\mathrm{a}} \\
(63.11)\end{array}$ \\
\hline Ac6 & $33.46 \pm 0.19^{d}$ & $\begin{array}{c}28.46 \pm 0.34^{\mathrm{c}} \\
(14.94)\end{array}$ & $\begin{array}{c}23.42 \pm 0.25^{\mathrm{b}} \\
(30.01)\end{array}$ & $\begin{array}{l}14.44 \pm 0.32^{\mathrm{c}} \\
(56.84)\end{array}$ & $\begin{array}{c}6.0 \pm 0.25^{\mathrm{f}} \\
(82.07)\end{array}$ \\
\hline Ac7 & $33.26 \pm 0.21^{\mathrm{d}}$ & $\begin{array}{c}31.47 \pm 0.15^{\mathrm{b}} \\
\quad(5.38)\end{array}$ & $\begin{array}{l}26.28 \pm 0.17^{\mathrm{a}} \\
\quad(20.98)\end{array}$ & $\begin{array}{l}22.20 \pm 0.16^{\mathrm{a}} \\
\quad(33.25)\end{array}$ & $\begin{array}{l}8.30 \pm 0.26^{\mathrm{b}} \\
\quad(75.05)\end{array}$ \\
\hline Ac8 & $4.32 \pm 0.22^{\mathrm{k}}$ & $\begin{array}{l}2.82 \pm 0.20^{j} \\
\quad(34.72)\end{array}$ & $\begin{array}{l}1.16 \pm 0.22^{\mathrm{i}} \\
\quad(73.15)\end{array}$ & $\begin{array}{l}0.77 \pm 0.21^{\mathrm{i}} \\
\quad(82.18)\end{array}$ & $\begin{array}{l}0.12 \pm 0.12^{c} \\
\quad(97.22)\end{array}$ \\
\hline Ac9 & $7.67 \pm 0.36^{j}$ & $\begin{array}{c}4.01 \pm 0.20^{\mathrm{i}} \\
(47.72)\end{array}$ & $\begin{array}{l}1.28 \pm 0.12^{\mathrm{i}} \\
\quad(83.31)\end{array}$ & $\begin{array}{l}0.08 \pm 0.13^{\mathrm{i}} \\
\quad(98.86)\end{array}$ & $\begin{array}{c}0^{\mathrm{f}} \\
(100)\end{array}$ \\
\hline Ac10 & $14.42 \pm 0.14^{\mathrm{h}}$ & $\begin{array}{c}11.02 \pm 0.21^{\mathrm{g}} \\
(23.58)\end{array}$ & $\begin{array}{c}6.70 \pm 0.28^{g} \\
\quad(53.54)\end{array}$ & $\begin{array}{l}2.13 \pm 0.16^{\mathrm{h}} \\
\quad(85.23)\end{array}$ & $\begin{array}{c}0^{\mathrm{f}} \\
(100)\end{array}$ \\
\hline Acll & $12.23 \pm 0.23^{\mathrm{i}}$ & $\begin{array}{c}10.47 \pm 0.29^{g} \\
(14.39)\end{array}$ & $\begin{array}{c}6.58 \pm 0.21^{\mathrm{g}} \\
(46.19)\end{array}$ & $\begin{array}{l}0.17 \pm 0.15^{\mathrm{i}} \\
\quad(98.61)\end{array}$ & $\begin{array}{c}0^{\mathrm{f}} \\
(100)\end{array}$ \\
\hline Ac12 & $52.36 \pm 0.28^{\mathrm{a}}$ & $\begin{array}{c}22.42 \pm 0.32^{\mathrm{e}} \\
(57.18)\end{array}$ & $\begin{array}{c}18.57 \pm 0.44^{\mathrm{d}} \\
(64.53)\end{array}$ & $\begin{array}{c}8.31 \pm 0.31^{\mathrm{e}} \\
(84.13)\end{array}$ & $\begin{array}{l}2.36 \pm 0.22^{\mathrm{d}} \\
\quad(95.49)\end{array}$ \\
\hline Ac13 & $46.50 \pm 0.22^{b}$ & $\begin{array}{c}34.21 \pm 0.19^{\mathrm{a}} \\
(26.43)\end{array}$ & $\begin{array}{c}14.50 \pm 0.22^{\mathrm{f}} \\
(68.82)\end{array}$ & $\begin{array}{c}5.12 \pm 0.41^{\mathrm{g}} \\
(99.98)\end{array}$ & $\begin{array}{c}0^{\mathrm{f}} \\
(100) \\
\end{array}$ \\
\hline Mean & $26.54 \pm 14.41^{\mathrm{a}}$ & $\begin{array}{c}19.06 \pm 10.98^{\mathrm{b}} \\
(28.19)\end{array}$ & $\begin{array}{c}12.56 \pm 8.58^{c} \\
(52.66)\end{array}$ & $\begin{array}{c}7.40 \pm 6.86^{\mathrm{d}} \\
(72.11)\end{array}$ & $\begin{array}{c}2.17 \pm 3.55^{\mathrm{e}} \\
(91.82)\end{array}$ \\
\hline
\end{tabular}

Mean values with \pm SE followed by different letters differ significantly according to Tukey's multiple range tests at $P<0.05$. Values in the parentheses indicate percent compared to the untreated control $\left(0 \mathrm{dS} \mathrm{m}^{-1}\right)$ plants.

sorghum varied among the varieties. Differences in growth among Phaseolus species under saline condition were also reported by Bayuelo-Jiménez et al. [35]. Salinity-induced reduction in plant growth has also been reported in tomato (Lycopersicon esculentum Mill.) seedlings [36] and in millet seedlings [11]. The effect of salinity on growth of plants might be due to interference of nutrient absorption and physiological water stress created by high salt concentrations in the root zone [37]. It may be due to toxic effect of the $\mathrm{NaCl}$ used, as well as unbalanced nutrient uptake by the seedlings [38]. Decreasing trend in plant height under salinity has also been reported in many crops like in rice $[39,40]$, in jute [10], in Ziziphus spina-christi (L.) wild [41], in tomato [25], in amaranthus [8], in turfgrass [17], in pea [16], and in barnyardgrass (Echinochloa crus-galli), horse purslane (Trianthema portulacastrum), junglerice (Echinochloa colona), and rice by Chauhan et al. [42].

Purslane is a leafy vegetable crop and shedding of leaves is a major symptom due to salinity stress. It was found that the general trend of the treatment reflects a regular reduction in the number of plant leaves with the increase of salt concentration compared with the plants of the control experiment. But in Ac5 a gradual increase of number leaves was observed in all the treatment levels compared to untreated control, though the highest increase (6.14\%) was observed at lowest level of salinity $\left(10 \mathrm{dS} \mathrm{m}^{-1}\right)$ with a consecutive decreasing of increasing rate (Table 6). However, these results of decreasing of number of leaves have been propped up by the findings of Welfare et al. [43] with their study on Cicer arietinum L. and López-Aguilar et al. [44] on the leaves of the tepary 
bean (Phaseolus acutifolius L.), cowpea (Vigna unguiculata L.), and wild bean (Phaseolus filiformis L). They opined that the treatment of sodium chloride reduced the number of leaves compared with control plants. Jamil et al. [45] stated that the reduction of leaf numbers on Cabbage (Brassica oleracea var. capitata L.) and Brassica oleracea var. botrytis L. is due to salinity treatments. The significant decrease in leaf number of beans (Phaseolus vulgaris L.) has also been reported by Gama et al. [46]. More than 50\% reduction in plant height, leaf number, total leaf area, leaf chlorophyll, and dry matter content in Ziziphus spina-christi (L.) Willd. at 80 and $160 \mathrm{mM}$ salinity has been reported by Sohail et al. [41]. The decrease of leaf numbers may be due to the accumulation of sodium chloride in the cell walls and cytoplasm of the older leaves. At the same time, their vacuole sap cannot accumulate more salt and thereby salt concentration decreases inside the cells, which ultimately leads to their quick death and cut down [4]. Uddin et al. [47] stated that the first noticed symptoms of salt overload are wilting plants and/or leaf "burn" or drying of the leaves, which are frequently originated by sodium and/or chloride toxicity. On the other hand, leaf death could be due to hastened senescence due to osmotic effect of the salt. This happens to be mostly applicable when considering the reproducibility of the responses in field condition [2].

Flowering is a life history feature resolute by plant genotype, genetic mechanism, the environment, and the interaction between them [48]. Flowering is also affected by several environmental factors such as photoperiod [49], temperature [50], herbivory [51], and water stress [52]. In our study purslane plants treated with different levels of $\mathrm{NaCl}$ salinity manifested significant reduction $(P<0.05)$ in flowering in both ornamental and common purslanes. The number of reduction of blooming followed the general trend of decreasing with increasing of salt concentration. Even at $30 \mathrm{dS} \mathrm{m}^{-1}$ salinity the flower reduction percentage reached 99\% and the lowest was around 33\% compared to untreated control. Due to further increase of salinity and at the highest level at $40 \mathrm{dS} \mathrm{m}^{-1}$ the flower reduction reached $100 \%$ for many accessions (Ac1, Ac4, Ac9, Ac10, Ac11, and Ac13); some of them (Ac2, Ac3, Ac8, and Ac12) had $>90 \%$ reduction and only three purslane accessions (Ac5, Ac6, and Ac7) were able to bloom around $20-40 \%$ of flowers (Table 8 ). The parallel results have been reported by Zapryanova and Atanassova [53] in ornamental flowering annual species Tagetes patula and Ageratum mexicanum. On the other hand, salt-induced flowering delays have been observed in Iris hexagona [54], in wild mustard (Sinapis arvensis), an annual, nonwetland, salt sensitive species [55], and in the salt-tolerant marsh species Cakile edentula [56] and Sporobolus virginicus [57]. The inhibition of spikelet development in wheat as well as spikelet sterility in rice has also been described by Läuchli and Grattan [58].

\section{Conclusions}

Augmented tolerance to salt stress in crop plants is necessary in order to increase productivity under cropping conditions with high salinity. The present work demonstrated that under saline condition purslane accessions show substantial variation in morphological characteristics. Among the selected 13 accessions, two accessions (Ac7 and Ac9) were quite able to produce satisfactory amount of dry matter with only $0-20 \%$ reductions even at the highest 30 and $40 \mathrm{dS} \mathrm{m}^{-1}$ salinities and were graded as tolerant (T); six accessions were graded as moderately tolerant (MT; Ac3, Ac5, Ac6, Ac10, Ac11, and Ac12) with $21-50 \%$ dry matter reduction; and five accessions were moderately susceptible (MS; Acl, Ac2, Ac4, Ac8, and Ac13) with 51-70\% dry matter reduction. Considering salinity effect on plant height, Ac5 was the least affected while Acl showed increase in plant height at moderate salinity $\left(20 \mathrm{dS} \mathrm{m}^{-1}\right)$, whereas Ac5 and Ac9 were very tolerant to salinity and produced increased number of leaves at all the salinity levels compared to control. Regarding flowering Ac5 and Ac7 were able to bloom about 30\% even at the highest salinity stress. So, among all 13 purslane accessions Ac5, Ac7, and Ac9 were the highest salt-tolerant accessions considering all the parameters evaluated. It was also found that the ornamental purslane showed more salt tolerance than common purslane. We hope that our findings will be very helpful for selecting purslane cultivars for commercial cultivation to fulfill the increased demands of fresh vegetables and for sustainable agriculture especially for saline areas.

\section{Conflict of Interests}

The authors declare that there is no conflict of interests regarding the publication of this paper.

\section{Acknowledgments}

The authors sincerely acknowledge UPM Research University Grant (01-02-12-1695RU) for financial support of the project and IGRF (International Graduate Research Fellowship, UPM) for Ph.D. Fellowship.

\section{References}

[1] W. Wang, B. Vinocur, and A. Altman, "Plant responses to drought, salinity and extreme temperatures: towards genetic engineering for stress tolerance," Planta, vol. 218, no. 1, pp. 1-14, 2003.

[2] R. Munns and R. A. James, "Screening methods for salinity tolerance: a case study with tetraploid wheat," Plant and Soil, vol. 253, no. 1, pp. 201-218, 2003.

[3] M. Tester and R. Davenport, " $\mathrm{Na}^{+}$tolerance and $\mathrm{Na}^{+}$transport in higher plants," Annals of Botany, vol. 91, no. 5, pp. 503-527, 2003.

[4] R. Munns, "Comparative physiology of salt and water stress," Plant, Cell and Environment, vol. 25, no. 2, pp. 239-250, 2002.

[5] G. W. Netondo, J. C. Onyango, and E. Beck, "Sorghum and salinity: I. Response of growth, water relations, and ion accumulation to $\mathrm{NaCl}$ salinity," Crop Science, vol. 44, no. 3, pp. 797-805, 2004.

[6] A. Incharoensakdi, T. Takabe, and T. Akazawa, "Effect of betaine on enzyme activity and subunit interaction of ribulose-1, 5bisphosphate carboxylase/oxygenase from Aphanothece halophytica," Plant Physiology, vol. 81, pp. 1044-1049, 1986. 
[7] S. P. Robinson and G. P. Jones, "Accumulation of glycine betaine in chloroplasts provides osmotic adjustment during salt stress," Australian Journal of Plant Physiology, vol. 13, pp. 659-668, 1986.

[8] E. N. Omami and P. S. Hammes, "Interactive effects of salinity and water stress on growth, leaf water relations, and gas exchange in amaranth (Amaranthus spp.)," New Zealand Journal of Crop and Horticultural Science, vol. 34, no. 1, pp. 33-44, 2006.

[9] H. B. Shao, Z. S. Liang, M. A. Shao, and B. C. Wang, "Changes of anti-oxidative enzymes and membrane peroxidation for soil water deficits among 10 wheat genotypes at seedling stage," Colloids and Surfaces B, vol. 42, no. 2, pp. 107-113, 2005.

[10] H. Ma, R. Yang, Z. Wang et al., "Screening of salinity tolerant jute (Corchorus capsularis \& C. olitorius) genotypes via phenotypic and phsiology-assisted procedures," Pakistan Journal of Botany, vol. 43, no. 6, pp. 2655-2660, 2011.

[11] H. Yakubu, A. L. Ngala, and I. Y. Dugje, "Screening of millet (Pennisetum glaucum L.) varieties for salt tolerance in semi-arid soil of Northern Nigeria," World Journal of Agricultural Sciences, vol. 6, no. 4, pp. 374-380, 2010.

[12] J. M. Wambua, M. N. Makobe, E. M. Njue, and A. B. Nyende, "Hydroponic screening of Sorghum (Sorghum bicolor L. Moench) cultivars for salinity tolerance," Journal of Agricultural Science and Technology, vol. 12, no. 2, pp. 82-91, 2010.

[13] L. Krishnamurthy, R. Serraj, C. T. Hash, A. J. Dakheel, and B. V. S. Reddy, "Screening sorghum genotypes for salinity tolerant biomass production," Euphytica, vol. 156, no. 1-2, pp. 15-24, 2007.

[14] M. Aslam, R. H. Qureshi, and N. Ahmed, "A rapid screening technique for salt tolerance in rice (Oryza sativa L.)," Plant and Soil, vol. 150, no. 1, pp. 99-107, 1993.

[15] G. B. Gregorio, D. Senadhira, and R. D. Mendoza, Screening Rice for Salinity Tolerance, Discussion Paper Series no. 22, International Rice Research Institute (IRRl), Manila, Philippines, 1997.

[16] M. A. Shahid, M. A. Pervez, R. M. Balal et al., "Screening of pea (Pisum sativum L.) genotypes for salt tolerance based on early growth stage attributes and leaf inorganic osmolytes," Australian Journal of Crop Science, vol. 6, no. 9, pp. 1324-1331, 2012.

[17] N. A. Zulkaliph, A. S. Juraimi, M. K. Uddin, M. R. Ismail, M. S. Ahmad-Hamdani, and U. A. Umme Nahar, "Screening of potential salt tolerant turfgrass species in Peninsular Malaysia," Australian Journal of Crop Science, vol. 7, no. 10, pp. 1571-1581, 2013.

[18] M. D. Peel, B. L. Waldron, K. B. Jensen, N. J. Chatterton, H. Horton, and L. M. Dudley, "Screening for salinity tolerance in alfalfa: a repeatable method," Crop Science, vol. 44, no. 6, pp. 2049-2053, 2004.

[19] A. Ayana and E. Bekele, "Geographical patterns of morphological variation in sorghum (Sorghum bicolor (L.) Moench) germplasm from Ethiopia and Eritrea: quantitative characters," Euphytica, vol. 115, no. 2, pp. 91-104, 2000.

[20] M. C. Shannon and C. M. Grieve, "Tolerance of vegetable crops to salinity," Scientia Horticulturae, vol. 78 , no. 1-4, pp. 5-38, 1999.

[21] N. K. Fageria, "Salt tolerance of rice cultivars," Plant and Soil, vol. 88, no. 2, pp. 237-243, 1985.

[22] SAS, “The SAS system for Windows," version 9.2 (TS1M0) Cary, NC, USA, SAS Institute Inc., 2013.

[23] S. Eker, G. Cömertpay, O. Konufikan, A. C. Ülger, L. Öztürk, and S. Çakmak, "Effect of salinity stress on dry matter production and ion accumulation in hybrid maize varieties," Turkish Journal of Agriculture and Forestry, vol. 30, pp. 365-373, 2006.
[24] A. R. Dadkhah and H. Grrifiths, "The effect of salinity on growth, inorganic ions and dry matter partitioning in Sugar Beet cultivars," Journal of Agricultural Science and Technology, vol. 8, pp. 199-210, 2006.

[25] M. A. Babu, D. Singh, and K. M. Gothandam, "The effect of salinity on growth, hormones and mineral elements in leaf and fruit of tomato cultivar PKM1," Journal of Animal and Plant Sciences, vol. 22, no. 1, pp. 159-164, 2012.

[26] J. Majkowska-Gadomska, A. Francke, and B. Wierzbicka, "Effect of soil substrate on the chemical composition of fruit of some tomato cultivars grown in an unheated plastic tunnel," Journal of Elementology, vol. 13, no. 2, pp. 261-268, 2008.

[27] M. Jamil, R. Shafiq, and E. S. Rha, "Response of growth, PSII photochemistry, and chlorophyll content to salt stress in four brassica species," Life Science Journal, vol. 11, no. 3, pp. 139-145, 2014.

[28] E. Ha, B. Ikhajiagba, J. F. Bamidele, and E. Ogic-Odia, "Salinity effects on young healthy seedling of Kyllingia peruviana collected from escravos, Delta state," Global Journal of Environmental Research, vol. 2, no. 2, pp. 74-88, 2008.

[29] L. Rui, S. Wei, C. Mu-xiang, J. Cheng-jun, W. Min, and Y. Bo-ping, "Leaf anatomical changes of Burguiera gymnorrhiza seedlings under salt stress," Journal of Tropical and Subtropical Botany, vol. 17, no. 2, pp. 169-175, 2009.

[30] S. A. Memon, X. Hou, and L. J. Wang, "Morphlogical analysis of salt stress response of pak choi," Electronic Journal of Environmental, Agricultural and Food Chemistry, vol. 9, no. 1, pp. 248-254, 2010.

[31] B. F. Dantus, L. Ribeiro, and C. A. Aragao, "Physiological response of cowpea seeds to salinity stress," Revista Brasileira de Sementes, vol. 27, no. 1, pp. 144-148, 2005.

[32] A. Orak and E. Ateş, "Resistance to salinity stress and available water levels at the seedling stage of the common vetch (Vicia sativa L.)," Plant, Soil and Environment, vol. 51, no. 2, pp. 51-56, 2005.

[33] B. Nedjimi, Y. Daoud, and M. Touati, "Growth, water relations, proline and ion content of invitro cultured Atriplex halimus sub sp. Schweinfurthii as affected by $\mathrm{CaCl}_{2}$," Communications in Biometry and Crop Science, vol. 1, no. 2, pp. 79-89, 2006.

[34] H. Yakubu, H. Usman, and A. M. Chiroma, "Screening of Sorghum Varieties for Salt tolerance in a sandy loam soil of Borno State, Nigeria," Nigerian Journal of Experimental and Applied Biology, vol. 7, no. 1, pp. 49-54, 2006.

[35] J. S. Bayuelo-Jiménez, R. Craig, and J. P. Lynch, "Salinity tolerance of Phaseolus species during germination and early seedling growth," Crop Science, vol. 42, no. 5, pp. 1584-1594, 2002.

[36] A. S. Hajer, A. A. Malibari, H. S. Al-Zahrani, and O. A. Almaghrabi, "Responses of three tomato cultivars to sea water salinity 1. Effect of salinity on the seedling growth," African Journal of Biotechnology, vol. 5, no. 10, pp. 855-861, 2006.

[37] O. A. Folorunso, A. M. Chiroma, and D. Abdullahi, "Influence $\mathrm{NaCl}$ salinity on soil properties and early growth of groundnut (Arachis hypogaea L.)," Environtropica, vol. 2, pp. 91-99, 2005.

[38] M. Jamil, D. B. Lee, K. Y. Jung, M. Ashraf, S. C. Lee, and E. S. Rha, "Effect of salt $(\mathrm{NaCl})$ stress on germination and early seedling growth of four vegetables species," Journal of Central European Agriculture, vol. 7, pp. 273-282, 2006.

[39] M. A. Hakim, A. S. Juraimi, M. M. Hanafi, A. Selamat, M. R. Ismail, and S. M. Rezaul Karim, "Studies on seed germination and growth in weed species of rice field under salinity stress," 
Journal of Environmental Biology, vol. 32, no. 5, pp. 529-536, 2011.

[40] M. Jamil and E. S. Rha, "Response of transgenic rice at germination and early seedling growth under salt stress," Pakistan Journal of Biological Sciences, vol. 10, no. 23, pp. 4303-4306, 2007.

[41] M. Sohail, A. S. Saied, J. Gebauer, and A. Buerkert, "Effect of $\mathrm{NaCl}$ salinity on growth and mineral composition of Ziziphus spina-christi (L.) willd," Journal of Agriculture and Rural Development in the Tropics and Subtropics, vol. 110, no. 2, pp. 107-114, 2009.

[42] B. S. Chauhan, A. S. K. Abeysekara, S. D. Kulatunga, and I. U. Madusanka, "Weed growth and grain yield, as affected by herbicides, in dry-seeded rice in Sri Lanka," Journal of Crop Improvement, vol. 27, no. 4, pp. 419-429, 2013.

[43] K. Welfare, A. R. Yeo, and T. J. Flowers, "Effects of salinity and ozone, individually and in combination, on the growth and ion contents of two chickpea (Cicer arietinum L.) varieties," Environmental Pollution, vol. 120, no. 2, pp. 397-403, 2002.

[44] R. López-Aguilar, A. Orduño-Cruz, A. Lucero-Arce, B. MurilloAmador, and E. Troyo-Diéguez, "Response to salinity of three grain legumes for potential cultivation in arid areas," Soil Science and Plant Nutrition, vol. 49, no. 3, pp. 329-336, 2003.

[45] M. Jamil, C. C. Lee, S. U. Rehman, D. B. Lee, M. Ashraf, and E. S. Rha, "Salinity $(\mathrm{NaCl})$ tolerance of brassica species at germination and early seedling growth," Electronic Journal of Environmental, Agricultural and Food, no. 4, pp. 970-976, 2005.

[46] P. B. S. Gama, S. Inanaga, K. Tanaka, and R. Nakazawa, "Physiological response of common bean (Phaseolus vulgaris L.) seedlings to salinity stress," African Journal of Biotechnology, vol. 6, no. 2, pp. 79-88, 2007.

[47] M. K. Uddin, A. S. Juraimi, M. R. Ismail, and M. A. Alam, "The effect of salinity on growth and ion accumulation in six turfgrass species," Plant OMICS, vol. 5, no. 3, pp. 244-252, 2012.

[48] B. Rathcke and E. P. Lacey, "Phenological patterns of terrestrial plants," Annual Review of Ecology and Systematics, vol. 16, pp. 179-214, 1985.

[49] Y. Shitaka and T. Hirose, "Effects of shift in flowering time on the reproductive output of Xanthium canadense in a seasonal environment," Oecologia, vol. 114, no. 3, pp. 361-367, 1998.

[50] S. M. Sandvik and Ø. Totland, "Short-term effects of simulated environmental changes on phenology, reproduction, and growth in the late-flowering snowbed herb Saxifraga stellaris L," Ecoscience, vol. 7, no. 2, pp. 201-213, 2000.

[51] D. Pilson, "Herbivory and natural selection on flowering phenology in wild sunflower, Helianthus annuus," Oecologia, vol. 122, no. 1, pp. 72-82, 2000.

[52] G. A. Fox, "Failure-time analysis: studying times-to-events and rates at which events occur," in Design and Analysis of Ecological Experiments, S. M. Scheiner and J. Gurevitch, Eds., Oxford University Press, Oxford, UK, 2001.

[53] N. Zapryanova and B. Atanassova, "Effects of salt stress on growth and flowering of ornamental annual species," Biotechnology \& Biotechnological Equipment, vol. 23, no. 2, pp. 177-179, 2009.

[54] P. A. van Zandt and S. Mopper, "Delayed and carryover effects of salinity on flowering in Iris hexagona (Iridaceae)," The American Journal of Botany, vol. 89, no. 11, pp. 1847-1851, 2002.

[55] M. L. Stanton, B. A. Roy, and D. A. Thiede, "Evolution in stressful environments. I. Phenotypic variability, phenotypic selection, and response to selection in five distinct environmental stresses," Evolution, vol. 54, no. 1, pp. 93-111, 2000.
[56] R. S. Boyd and M. G. Barbour, "Relative salt tolerance of Cakile edentula ( Brassicaceae) from lacustrine and marine beaches," The American Journal of Botany, vol. 73, no. 2, pp. 236-241, 1986.

[57] K. C. Blits and J. L. Gallagher, "Morphological and physiological responses to increased salinity in marsh and dune ecotypes of Sporobolus virginicus (L.) Kunth," Oecologia, vol. 87, no. 3, pp. 330-335, 1991.

[58] A. Läuchli and S. R. Grattan, "Plant growth and development under salinity stress," in Advances in Molecular Breeding toward Drought and Salt Tolerant Crops, pp. 1-32, 2007. 

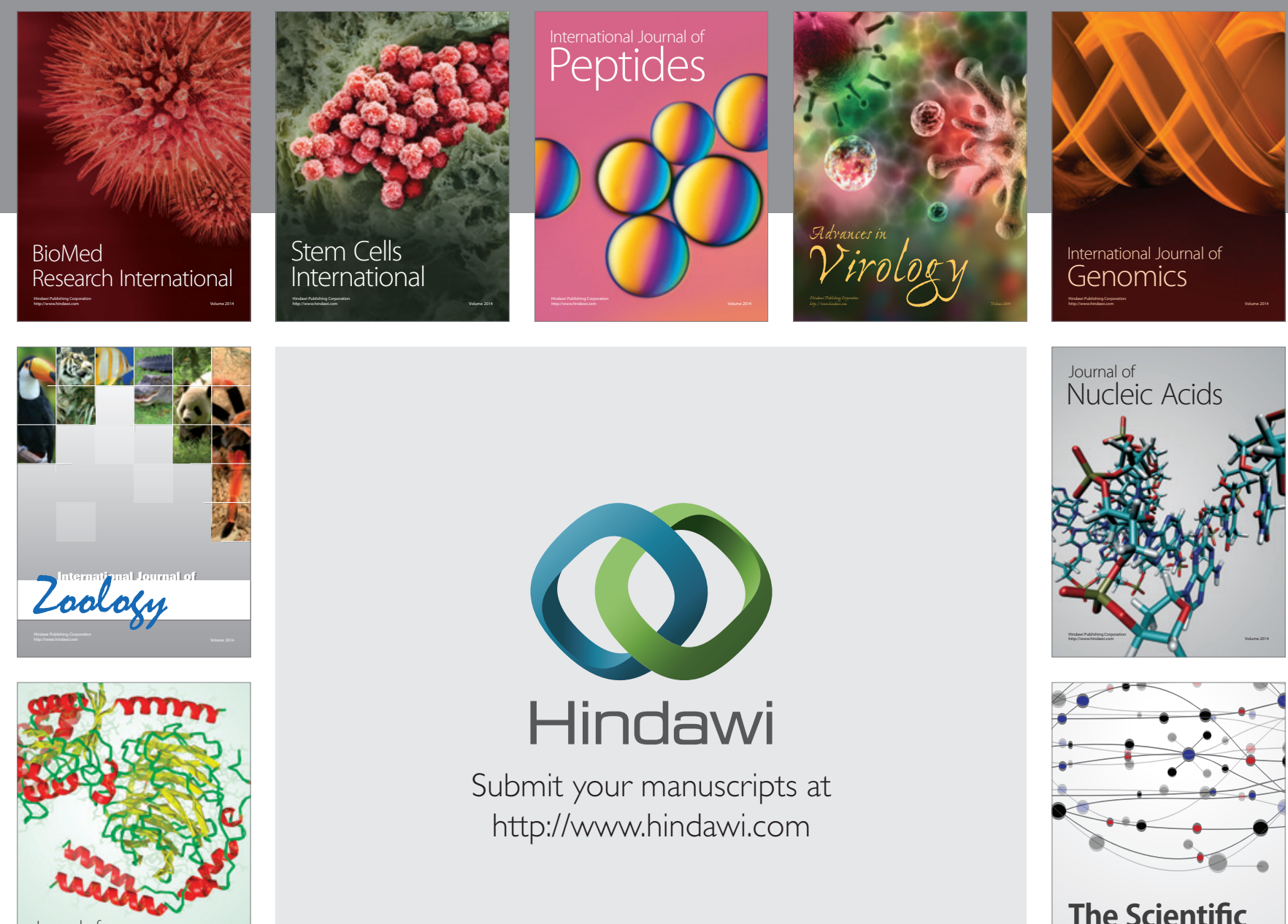

Submit your manuscripts at

http://www.hindawi.com

Journal of
Signal Transduction
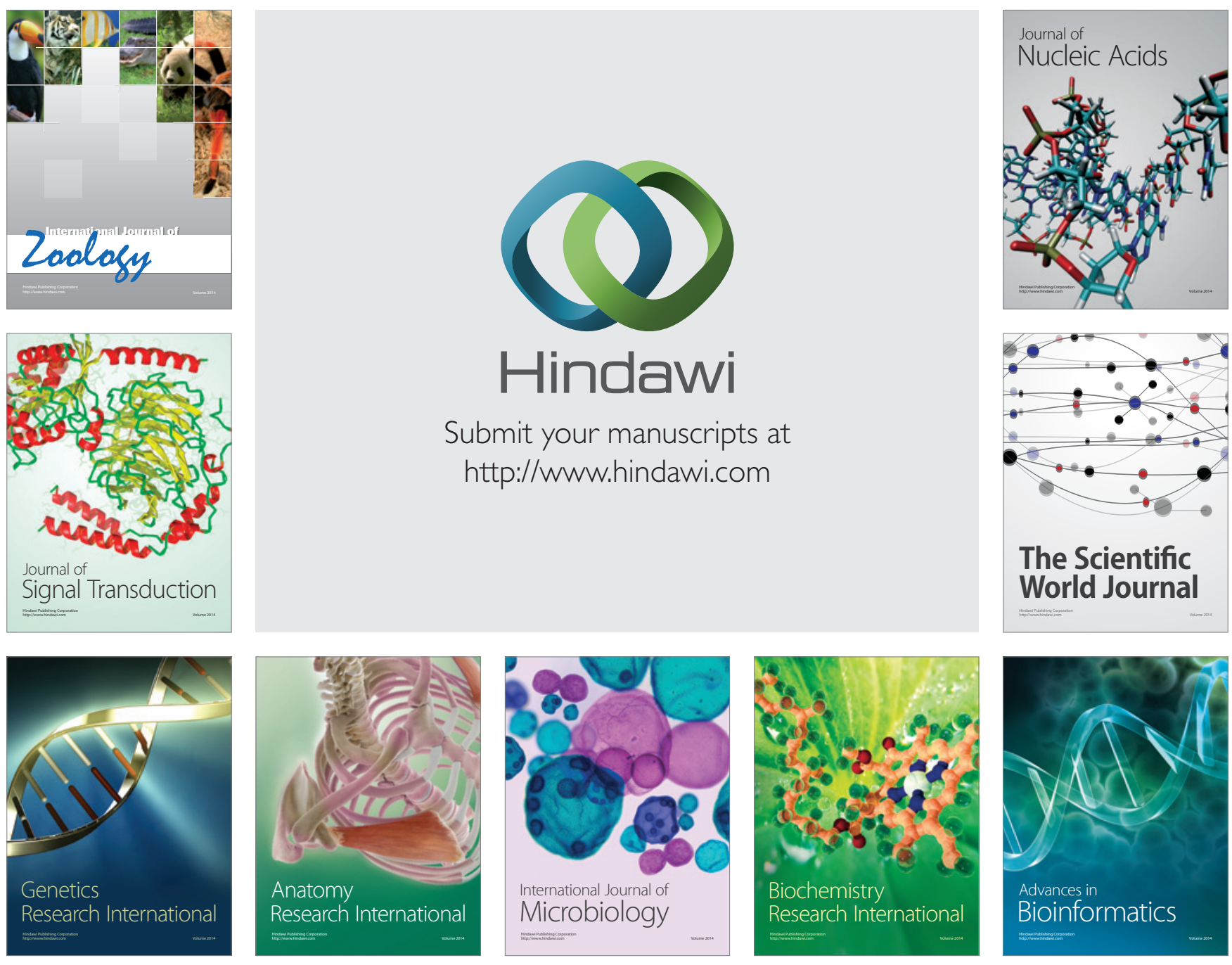

The Scientific World Journal
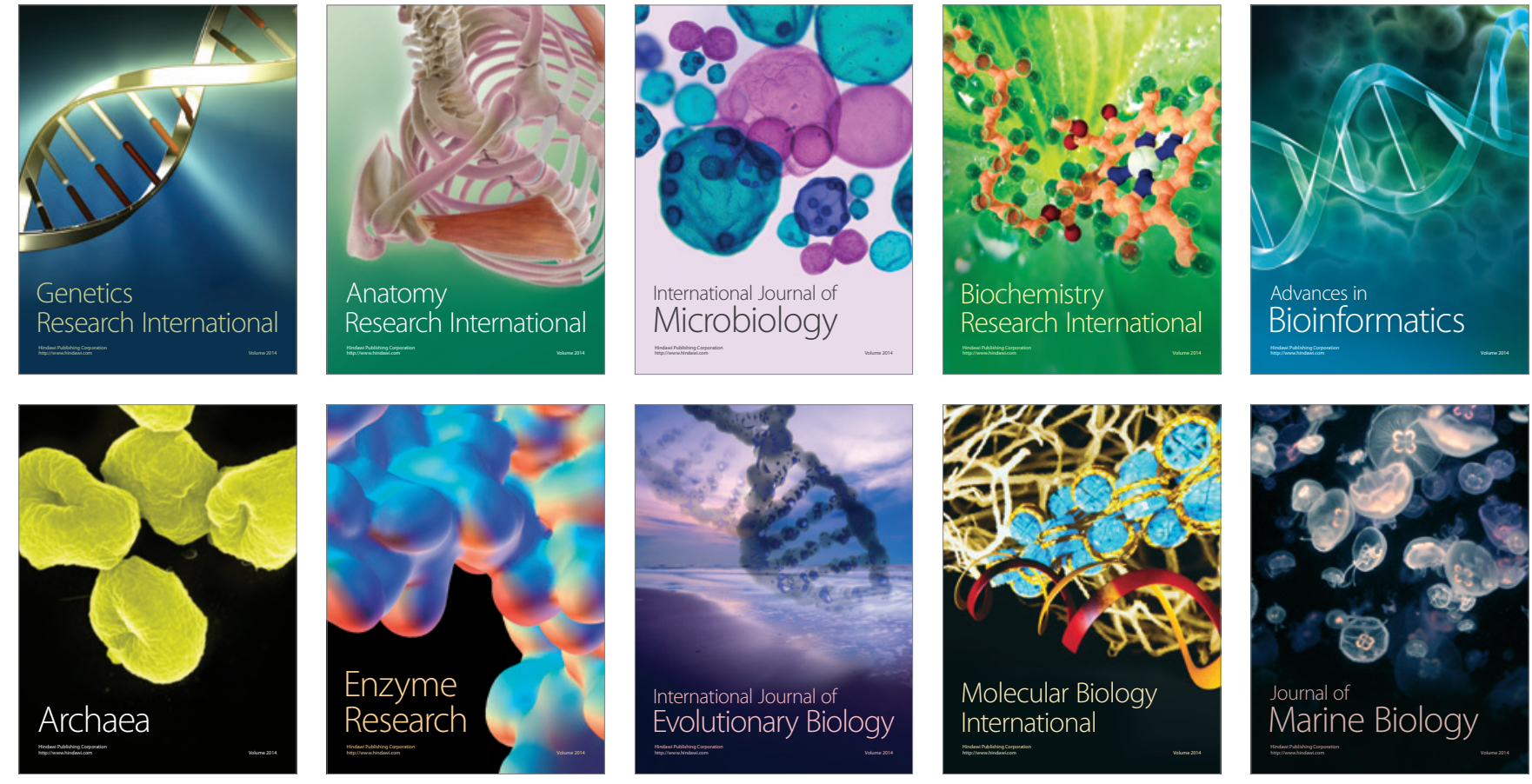